\title{
A RECONSTRUCTION OF THE PALEORELIEF OF VILNIUS' CROOKED CITY BY INTERDISCIPLINARY METHODS
}

\author{
Virgilijus Pugačiauskas, Saulius Sarcevičius, Oksana Valionienè
}

ABSTRACT The article analyses issues of the Crooked Castle (Curvum castrum) of Vilnius in the Middle Ages. Having located this castle in the 1930s-1960s in the territory of the current Kalnu Parkas, the necessity arose to define its relationship with the Lower and Upper castles. To achieve this goal, researchers first of all had to answer the important question of how the current relief differs from what it was in the 14th century. A group of scholars from the Lithuanian Institute of History undertook to implement this task. On the basis of interdisciplinary research methods, the article presents a reconstruction of the paleorelief of the hills, and discusses the scale of changes in the terrain and their causes.

\section{Introduction}

The area encompassing block 73 of the city of Vilnius, formerly called Altarija, but now better known by the name of Kalnų Parkas, which was given to it after the Second World War, is mentioned in written sources from the 14th century. Its history is closely connected with the formation of the Lithuanian capital. It is believed that the wooden Crooked Castle (Curvum castrum) was here in the 14th century. ${ }^{1}$ Unfortunately, the sparse written sources surviving until our days, and the fairly late cartographic material, do not so far allow us to reconstruct comprehensively the development of the complex. Many issues are still in dispute: only the fundamental facts of the existence of the Crooked Castle are known.

For a long time, relying on the chroniclers Jan Długosz, Maciej Stryjkowski and the first historian of Lithuania Albertas Kojelavičius, the Crooked Castle was identified with Vilnius' Lower Castle, and

${ }^{1}$ Codex epistolaris Vitoldi magni ducis Lithuaniae, ed. A. Prohaska (Monumenta medii aevi historica res gestas Poloniae illustrantia) VI (Kraków, 1882), p. 1009. This term was probably used for the first time in the 1416 complaint of Jogaila to the Council of Constance: 'in quo tria castra sunt situata, quorum unum vocatur Curvum castrum' 
called the Crooked City. ${ }^{2}$ Michał Baliński, commenting on the origin of the name of the Šventaragis Valley, stated that the name of this wedge-shaped valley Swiat-Roh was later mentioned by the Ruthenians as the Crooked Castle (Kriwgorod). ${ }^{3}$ Józef Ignacy Kraszewski, in his study of the history of Vilnius published in $1840,{ }^{4}$ Władisław Zahorski and Juliusz Kloss in their published guidebooks to Vilnius (1923 and 1929), as well as the publishers of archive documents on the Vilnius capitula, Jan Fijałek and Władysław Semkowicz, equated the Lower Castle with the Crooked City. ${ }^{5}$ In the plan for the management of green spaces in Vilnius created in the 1920s and 1930s, the Lower Castle is called the Crooked City. ${ }^{6}$

The first historian to substantiate with arguments the existence of three separate Vilnius castles, the Upper, Lower and Crooked, was V. Vasilevsky, reading his report in 1893 at the Ninth Congress of Russia's Archaeologists in Vilnius. However, he located the Crooked Castle on Bokšto (Tower) St, the place of the current Artillery Bastion. ${ }^{7}$ Mieczysław Limanowski supported this idea in his work Najstarsze Wilno (Oldest Vilnius) (1930), as did Władysław Semkowicz in his article published in 1931 about the Vilnius lieutenant Hanul. ${ }^{8}$ The Polish archaeologist W. Holubowicz agreed with the idea of the existence of the Crooked, third Vilnius castle. After excavations carried out in 1933 and 1939 in the former area of Altarija, he located the Crooked Castle on Bekešas Hill (Fig. 1). Near this hill, he discovered a dense, three-horizon wooden building, which

${ }^{2}$ M. Stryjkowski, Kronika Polska, Litewska, źmudzka, 1 (Warsaw, 1846), p. 89, 372; M. Balinskis, Vilniaus miesto istorija (Vilnius, 2007), pp. 18-19, 107-109.

3 Ibid., p. 19.

${ }^{4}$ J.I. Kraszewski, Wilno od początków jego do roku 1750 (Wilno, 1840), p. 28 : 'zaczal Gedymin zaloźenie miasta od budowy dwoch zamkow, jednego na gorze Turzej, drugiego w dolinie zu anej Krzywa-Krivve', z basztami, palissada, blankami. Wyiszy byl murowany, niźszy z drzewa; - ten nazwisko Krzywego nosil od imienia daliny. Kolo nich u stop gor poczęlo sięrozklada ćmiasto.'

5 A. Tautavičius, 'Vilniaus pilies teritorijos archeologiniai kasinejimai', Valstybinès LTSR architektūros paminklu apsangos metraštis (Vilnius, 1960), pp. 41-44; idem., 'Kreivosios pilies lokalizavimo klausimu', Vilniui 650 metu (Vilnius, 1976), p. 100.

${ }^{6}$ LVIA, f. 1135, ap. 12, b. 110.

${ }^{7}$ V.C. Vasilevskii, 'Gde nahodylsia Vilenskii Kryvoi gorod?', Trudy IX arkheologicheskogo s'ezda v Vilne (1893), t. 2 (Moscow, 1897), pp. 120-121.

${ }^{8}$ Tautavičius, 'Kreivosios pilies', pp. 100-101. 
he dated to the 12 th-14th centuries. ${ }^{9}$ M. Morelowski noted in 1940 that the existing range of hills includes not only Bekešas Hill, which, incidentally, was the lowest, but also other mounds that were larger and taller, primarily Plikasis (Bald), which is also called Kreivasis (Crooked) or Three Crosses, and also Table Hill. ${ }^{10}$ Although many historians agreed with the location idea of Hołubowicz, ${ }^{11}$ there were doubters. ${ }^{12}$ These doubts were finally dispelled only after research in 1956 by the archaeologist Adolf Tautavičius in the valley situated between Table and Crooked hills, now known as the Valley of Songs (Fig. 1). ${ }^{13}$ Summing up his studies, the archaeologist disagreed with the view of Holubowicz that the Crooked Castle was on Bekešas Hill. He said that the Crooked Castle could stand only on the highest, Plikasis Hill, because it is no coincidence that Bald Hill was known from old times as Crooked. Next to the Crooked Castle he saw the founded city. ${ }^{14}$ Subsequent archaeological investigations on Bald Hill which Vytautas Daugudis conducted in 1988-1991 proved that there actually existed defence fortifications on it: ramparts and wooden defensive walls (Fig. 1). ${ }^{15}$ In the opinion of the archaeologist, in the first millennium AD there were fortified settlements on

${ }^{9}$ W. Hołubowicz, Krzywy gród z XIV w. na górze Bekieszowej w Wilnie (Vilnius, 1939), no. 1, pp. 28-30; V. Golubovič, E. Golubovič, 'Krivoi gorod Vilno'. Kratkye soobshcheniye o dokladakh i polevikh isledovaniakh instytuta materialnoi kultury (1945), t. 9, pp. 114-126.

${ }^{10}$ Tautavičius, 'Kreivosios pilies lokalizavimo klausimu', p. 101.

${ }^{11}$ J. Jurginis, V. Merkys, A. Tautavičius, Vilniaus miesto istorija (Vilnius, 1968), pp. $39-40$.

12 J. Ochmański, 'Krzywy gród Wilenski. Proba lokalizacji', Zapiski historvczne, 36 (1971), p. 85. Tautavičius analysed Ochmański's hypothesis, 'Kreivosios pilies lokalizavimo klausimu', pp. 102-104. For more information about the investigation of this hypothesis see S.C. Rowell, 'Ką ankstyvieji rašytiniai šaltiniai byloja apie Kreivosios pilies vietą', Lietuvos pilys, 4 (2008), pp. 112-126.

13 A. Tautavičius, Archeologinių kasinėjimų Vilniuje Dainų slènyje 1956. IV. 24-V.14 dienoraštis, LIIA, f. 1, b. 40; idem, 'Iš XIV a. Vilniaus gyventojų buities', Iš lietuvių kultūros istorijos, 1 (Vilnius, 1958), pp. 94-103.

${ }^{14}$ Tautavičius, 'Vilniaus pilies', pp. 43-44.

${ }^{15}$ V. Daugudis, 'Plikojo kalno archeologinių tyrimų ataskaita', 1988, LIIA, Nr. 1543; idem, 'Plikojo kalno archeologinių tyrimų ataskaita', 1989, ibid., Nr. 1611; idem, 'Vilniaus Plikojo kalno archeologiniai kasinejimai', Archeologiniai tyrinejjimai Lietuvoje 1988 ir 1989 metais (Vilnius, 1990), pp. 127-130; idem, 'Vilniaus Plikojo kalno archeologiniai kasinejjimai', Archeologiniai tyrinëjimai Lietuvoje 1990 ir 1991 metais (Vilnius, 1992), pp. 41-44; idem, 'Nauji duomenys apie Vilniaus Plikojo (Trijų Kryžių) kalno praeitį', Lietuvos mokslas, T. 2, kn. 2-3 (Vilnius, 1994), pp. 162-175; idem, Iš Vilniaus miesto praeities (Vilnius, 1993), pp. 34-48. 


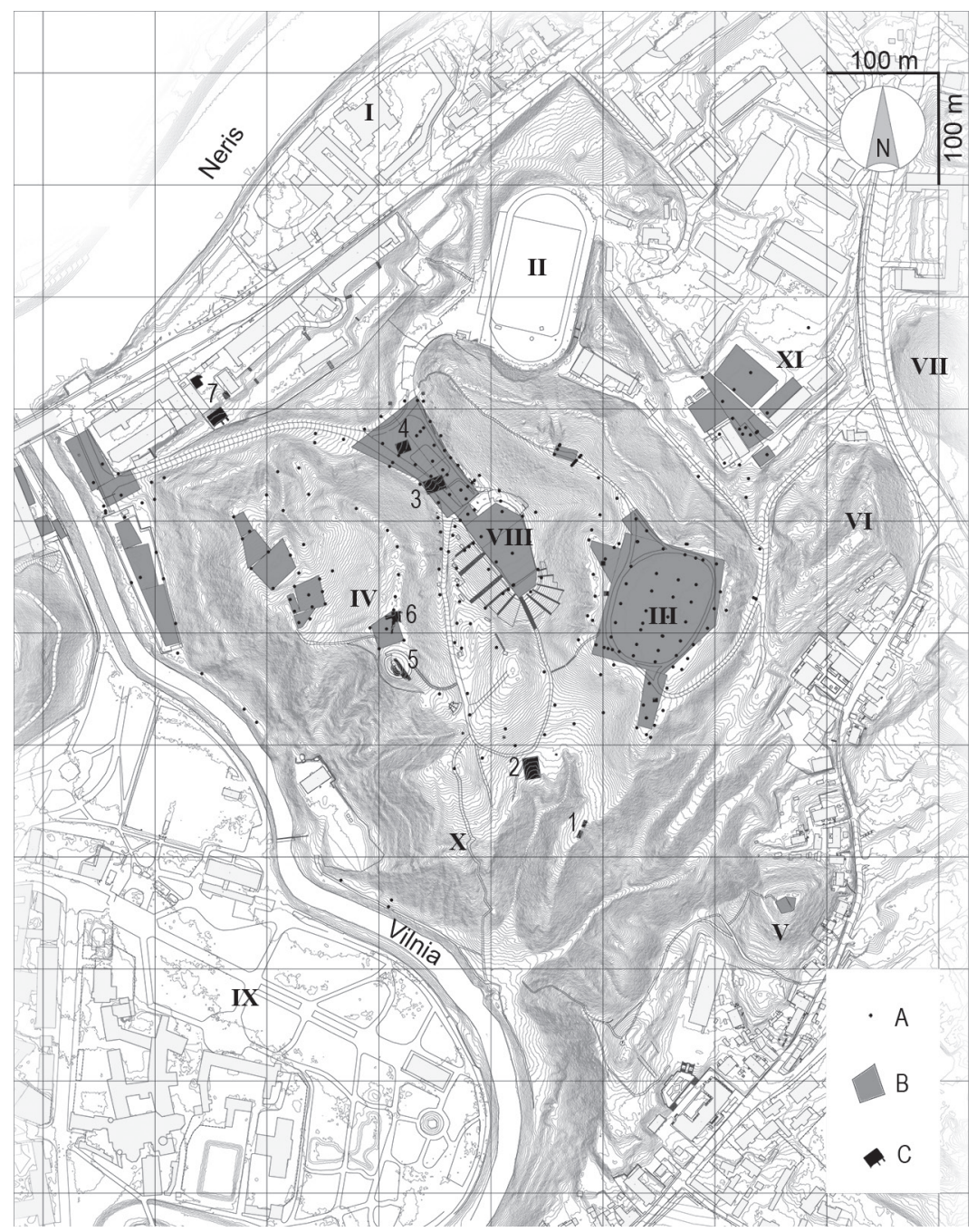

Fig. 1. Kalnų Parkas Research. Consolidated plan of the existing terrain (author O. Valionienè) 
Bald Hill which belonged to the Baltic tribes. The second horizon of defensive fortifications was dated to the 12 th and 13 th centuries. The last horizon of fortifications is dated to the 13 th and 14 th centuries. ${ }^{16}$ The author of the research emphasised that in Lithuania we have almost no analogues to the detected burned defensive fortifications of the latest period on Bald Hill. In his opinion, Crooked Castle at the beginning of the 13 th and 14 th centuries was initially more strongly fortified than Gediminas Hill in Vilnius, and perhaps played a more important role than we think.

In the 1990s, archaeologists determined de visu that the Crooked Castle and the city that was near it took up not only Bald, Table and Bekešas hills and the areas between them, but also the closest access from the north, the River Neris. This conclusion is based on archaeological studies which took place in the area of the existing buildings at T. Kosciuškos St 3 (Fig. 1). ${ }^{17}$

In recent years, one can feel the increased attention of scholars to issues of Vilnius' Crooked Castle. ${ }^{18}$ The current field of interest among researchers has long grown past the stage of locating the Crooked Castle, which was relevant to historians in the 19th and the first half of the 20th century, and transferring to a search for more concrete decisions related to the castle. The main attention is directed to topographical surveys.

The architect Sigitas Lasavickas was the first to undertake a study of the topography of Kalnų Parkas. In the 1960s, based on characteristics determining the existing relief, he tried to define the contours of the Crooked Castle (City). His suggested vision of the castle essentially did not change until the 1980s, when on the basis of his insights, the boundaries of the State Cultural Reserve of the

${ }^{16}$ Daugudis, 'Nauji duomenys', pp. 167-168.

17 A. Vaicekauskas, Archeologinių tyrimų Vilniuje, Kosciuškos g. Nr. 3, ataskaita, LIIA, f. 1, b. 2474; S. Sarcevičius, 1997 m. Vilniuje, T. Kosciuškos g. Nr. 3, vykdytų archeologinių tyrimų ataskaita, 1998 m., t. I-III, ibid., b. 2895.

18 S. Sarcevičius, 'Dainų slènio paslaptys', Lietuvos pilys, 4 (2009), pp. 75-94; S. Sarcevičius, O. Valionienè, 'Vilniaus Kreivosios pilies paleoreljefas, jo ịtaka miesto genezei', Lietuvos pilys, 6 (2011), pp. 128-148; D. Michelevičius, S. Sarcevičius, 'Šiuolaikinių geofizikinių, geologinių ir kartografinių metodų taikymas Vilniaus Kreivosios pilies beieškant', Geologijos akiračiai, 1 (Vilnius, 2012), pp. 7-14; S. Sarcevičius, 'Stalo kalno paleoreljefo tyrimai Vilniuje', Miestu praeitis, 3 (2012), CD Publication; G. Vaitkevičius, L. Kiškienė, 'Kreivasis miestas', Miestu praeitis, 2 (2010), CD Publication; G. Vaitkevičius, 'Vilniaus tapsmas'; idem, 'Vilniaus ịkūrimas', Vilniaus sąsiuviniai, 1 (2010), pp. 56-59; idem, 'İžanginès mintys apie Kreivaji miestą', Lietuvos pilys, 5 (2009), pp. 32-43. 
Vilnius Castles, which was being established, were defined. ${ }^{19}$ Based on the surviving drawings of Lasavickas, and especially the comments on them, we can form his proposed diagram of the Crooked Castle: the main castle was on Crooked (Bald, Three Crosses) Hill, from which towards the Neris were the extending ridges surrounding the inner space of the castle. The Crooked Castle, framed by a wooden defensive wall, includes Bald, Table and Bekešas hills, and three plateaus between the hills. A sacred significance is assigned to Gediminas Grave Hill (Fig. 3, Au18), being already beyond the defensive enclosure. The hills near the current Olandu (Dutch) St, which are also just outside the area of the Crooked Castle, are called guard hills (žvalgakalniais) (Fig. 3, Au16, 17). Beyond the defensive fence, the author locates two baileys, one between Crooked Hill and the River Neris, and the other to the northeast of Table Hill. ${ }^{20}$

We have to state that the author made his conclusions on the basis of the existing topography, often not having specific data, in practice according to his intuition. The work of Lasavickas shows that the investigations of the existing topography of the hills not only had obvious advantages, but also programmed disadvantages. Can one reasonably discuss the boundaries of the Crooked Castle or the course of its building, and understand the mutual relations between different parts of the castle, without reliable data on the resulting intensity of the cultural layer in different areas of the castle, and not having determined and evaluated the properties of the original hilly terrain (paleorelief) and its changes over the course of history?

The reconstruction of the paleorelief of the Crooked City became the main object of the research by Gediminas Vaitkevičius and Lidija Kiškienè. To resolve this problem, the authors used the

${ }^{19}$ S. Lasavickas, Vilniaus pilių gynybinè sistema M 1:2500. 1960 m., LMA 234, no. $778,1.1$; idem, Drawing without a title with a plan of the Crooked Castle, ibid., 1. 2; idem, Reconstruction of the Crooked Castle. 199204 07, ibid., 1. 8, 10; idem, The zoning plan of the historical reserve of the castles of Vilnius, ibid., 1. 3; idem, The historical-monumental reserve of the castles of Vilnius. Plan of the borders of the territory and the protective zone. M 1:2000, ibid., 1. 4; idem, Plan of the protective zone of the National Park of the Castles of Vilnius. 1987 06-07, ibid., 1. 12; idem, Plan of the zoning of the National Park, ibid., 1. 2; idem, National Park of the Vilnius Castles of the Lithuanian Nation in 1989, ibid., 1. 13; idem, National Park of the Castles of Vilnius. 1506 1989, ibid., 1. 17.

${ }^{20}$ The proposal of Lasavickas, the area of the historical-archaeological reserve territory of the castles of Vilnius, see ibid., 1. 4-9. 


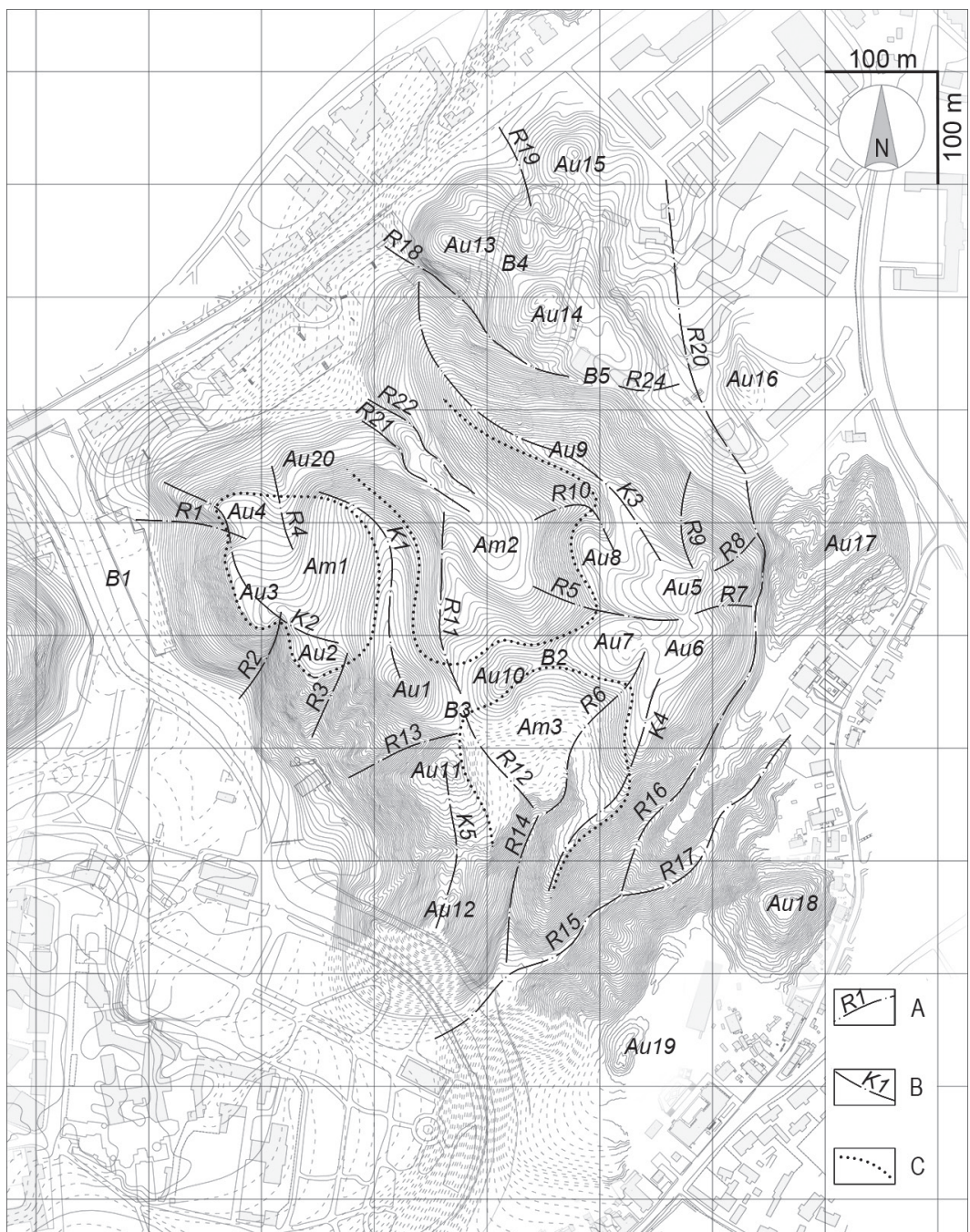

Fig. 3. Reconstruction of the primary relief of Kalnų Parkas.

Horizontal step - one metre (O. Valionienè) 
19th-century plans of the military fortifications, archaeological data, the rather sparse at that time geological material, and geomorphological investigations of the hills. ${ }^{21}$ In their publication, the authors rightly drew attention to the clear signs of the natural erosion of the hills along the River Vilnia, and changes observed in the terrain of Bald Hill, in the former environment of Bekešas Hill, and in the southern amphitheatre and the Valley of Songs (Fig. 1). In analysing this data, the authors tried to reconstruct the original terrain of the hill. The main thesis of this work is that during the existence of the Crooked Castle, the current square of Bald Hill was much larger, and it extended to the east and south, where today remain nameless ridges separated from Bald Hill by wide and deep ravines. This conclusion is reached by raising the amount of natural erosion from slipped soil on the top of Bald Hill calculated by the authors. In this way, the square of Bald Hill becomes significantly wider, and acquires a sufficient size in which the citadel of the Crooked City could have stood. In the light of the latest research, we have to point out in this methodological scheme the scale of the human invasion in the area of Kalnu Parkas at the time of the installation of military fortifications in the 19th century and their operation, when the dug up soil could have been spread in different places in the hilly area, and not necessarily next to the dug out hill. However, this in no way detracts from the fact fixed by the authors about the massive changes in the paleorelief of the Crooked Castle. The reasonable idea about the tactics of ring defence existing at that time essentially complements the map of the Crooked Castle presented by Lasavickas. How does this map fit into the scheme of the latest research conducted by scholars from the Lithuanian Institute of History in the area of Kalnu Parkas ${ }^{22}$ and its context?

The purpose of this article is to analyse changes in the terrain in the Hill of Three Crosses. To resolve the question of the recon-

\footnotetext{
${ }^{21}$ Vaitkevičius, Kiškienè, Kreivasis miestas, CD laikmena; Vaitkevičius, Ǐžanginès mintys, pp. 32-43.

22 S. Sarcevičius, Vilniaus pilių kultūrinio valstybinio rezervato teritorijoje esančiame Dainų slėnyje (A 1961K) vykdytų archeologinių žvalgomujjų (geologinių, geofizinių) tyrimų ataskaita, 2008, LIIA, f. 1, b. 5060; idem, 'Tyrimai Vilniuje, Kalnų parko teritorijoje esančiame Stalo kalne', Archeologiniai tyrinejjimai Lietuvoje 2009 metais (Vilnius, 2010), pp. 182-185; V. Pugačiauskas, S. Sarcevičius, D. Michelevičius, O. Valionienė, Lietuvos mokslo tarybos mokslinių tyrimų projektas 'Kompleksinių tyrimų taikymas Vilniaus Kreivojo miesto (Curvum Castrum) tyrimuose', 2010-2011.
} 
struction of the paleorelief of the hills, interdisciplinary (historical, cartographic, geological and geophysical) methods were used. After discussing these changes, we will try to find out the scale of the erosion of the hills and its causes, to evaluate the influence of the highlighted primary relief in the urban scheme of the Crooked City.

\section{The terrain of the hills and 19th century military fortifications. A historical study}

The most intensive changes of the terrain known to us in the project area are linked with the 1831 military fortifications (destroyed in 1878), which were built as a response to the uprising that took place against the Imperial Russian government. ${ }^{23}$ The fortifications were built in half a year, from 2 June to 2 November 1831. Regarding the preparatory stage, we have to note that the topographical unit of the Russian Ministry of War only had a small and inaccurate plan of the castles area of Vilnius, so the designers were initially forced to use a plan made by French military engineers in 1812, about which we do not have precise information. ${ }^{24}$ The preparatory work on the project began at the beginning of April, when the decree of the Emperor Nicholas I for the construction reached the director engineer of the Engineering Department of the Ministry of War, Adjutant General Karl Operman (1765-1831), who had great experience in the construction of fortresses in the early 19th century (as head of the construction of the Bobruisk and Daugavpils fortresses, and designer of the Brest-Litovsk fortress). ${ }^{25}$ The work in designing the Vilnius fortifications in this department was completed in a few weeks. The project was financed from funds for the Vilnius-Daugavpils road.

${ }^{23}$ Feliksas Sliesoriūnas, analysing the main topic, the history of the formation of Gediminas Square from the end of the 18th century until the beginning of the 20th century, briefly discussed the main questions of the construction of the 1831 fortifications of Vilnius and their further exploitation in the entire territory of the castles, and stated that this military construction did a lot of damage to the urban development of Vilnius, because it destroyed a large part of the architectural ensemble formed over the centuries, in the case of the Hill of Three Crosses digging ditches and pouring defensive embankments. F. Sliesoriūnas, Gedimino aikštè Vilniuje (Vilnius, 1980), pp. 17-53.

${ }^{24}$ The 31 August 1831 letter of Count Karl Operman, RGVIA, f. 478, ap. 1, b. $7,1.452$.

25 The letter from the head of the Russian army's general staff reached the department on 6 April 1831. Sliesoriūnas, Gedimino aikštè Vilniuje, p. 17; Istoryja krepostei (St Petersburg, 1995), pp. 103, 105, 109. 
Engineer Major General Nikolai Klimenko (1784-1840), who had experience in the construction of the Daugavpils (Dünaburg) fortress, was appointed chief commander of the construction. Colonel Kapela, who was busy in the construction of the Daugavpils fortress, was posted to execute the construction works. ${ }^{26}$

From Klimenko's master plan of the Vilnius fortifications, signed in 1831, we can form a picture of how the fortifications built on the Hill of Three Crosses looked. An artificial line of defence, consisting of ditches and ramparts, surrounded the area of the Hill of Three Crosses. It started from the bridge over the Vilnia on the right bank. The main entrance to the area of the fortifications was here. The line surrounded the Chodasevičius house (property no 1353) and rose up the slope of the hill towards the peak of the Hill of Three Crosses, surrounding it from the city side. However, by the right bank of the Vilna, the line broke, because a natural obstacle extended its function: the steep slope of the hill and the river. ${ }^{27}$ Beyond the defensive line, in front of Table Hill, we can see a separate caponier with an artillery position connected by an underground passage. At the highest point, the peak of the Hill of Three Crosses, on the hill of the second terrace, in the declining oval area on this side of the Neris, surrounded by a small ditch, the builders built a pill-box, ${ }^{28} \mathrm{a}$ building to accommodate soldiers. This infrastructure of the Hill of Three Crosses fortifications remained without major changes during the whole period of its maintenance. In this first plan were several more engineering installations: on Table Hill a massive rectangularshaped fortification is marked, joined to the Hill of Three Crosses by an underground passage in which (the current Valley of Songs) it was intended to install another pill-box for infantry, as well as a caponier. The passage was to be connected to the main fortification by the previously mentioned caponier located in front of the defensive rampart. However, this idea, as later plans for the fortifications of the Hill of Three Crosses testify, was not fully realised. The reason is not clear, but we can assume that saving money, as well as the

${ }^{26}$ The 26 April 1831 letter from the head of the general staff to the temporary military governor-general of Vilnius and Grodno General-adjutant M. Chrapovicki, LMAVB, f. 20-5184, 1. 6.

${ }^{27}$ The 1831 master plan of the fortifications of Vilnius, LMAVB, f. 229-963, 1. 1.

${ }^{28}$ A defensive structure designed to shoot in all directions with the four-corner plan of a Greek cross with shooting openings. A ditch and an embankment surrounded it. Designed for close defence. They were built near bridges, mountain crossings. Enciklopedinis karybos žinynas (Vilnius, 2008), p. 82. 
weakening of the intensity of the uprising in the whole land, had an influence on it. The instruction to Major General Klimenko was to devote exclusive attention to the fortification marked on the 1831 plan with the letter A, or more precisely, the fortification of the Hill of Three Crosses, which had to be done so that it would ensure good flanking defence. It had to be equipped with ten positions for cannons of various calibres. ${ }^{29}$ From the plan, we can see that Castle Hill took the central place in the system of Vilnius' fortifications, while the Hill of Three Crosses and the area on the right bank of the River Neris were for flanking positions. The River Vilnia, over which a pedestrian bridge was built, separated the fortifications of the Hill of Three Crosses from the central part of Castle Hill. The second communication artery was the bridge across the Vilnia at its mouth; however, that was beyond the limits of the fortifications of both defensive lines. Thus, the flanking fortifications of the Hill of Three Crosses were an integral part of the fortifications of Vilnius. However, this flanking position, separated by two river beds from the central part of Castle Hill and by the wide bed of the River Neris from the second flanking fortifications, ensured its garrison additional possibilities to carry out mobile maneuvres: to act together and, in case of need, independently.

Three properties in the 1808 Vilnius city plan, labelled with the numbers 1351, 1352 and 1353, the Chodasevičius house, ${ }^{30}$ fell into the construction zone of fortifications at the foot of the hill. In the first property, the defensive line and the main entrance were to be built. It is known that in 1808 in property 1351, located on the right bank of the Vilnia (by the bridge over the river), in the property of Chodasevičius there was only a wooden house with two rooms. ${ }^{31}$ On the Vilnius city plan made in 1829 , one large and one small wooden building are marked. ${ }^{32}$

Property no 1352 was inside the inner territory of fortifications, beyond the defensive line, so it was planned to adapt its brick buildings, which were in good condition, for military purposes. It

${ }^{29}$ Letter of 25 April 1831 to Major-General Klimenko, LMAVB, f. 20-5184, 1. 5; Description of the fortifications of Vilnius, RVKIA, f. 478, ap. 1, b. 7, 1. 577-578.

${ }^{30}$ Part of the 1808 plan of Vilnius, V. Drema, Dingęs Vilnius (Vilnius, 1991), p. 43.

${ }^{31}$ List of the 1808 possessions of Vilnius, LVIA, f. 458, ap. 1, b. 720, 1. 16; V. Drèma, Vilniaus namai archyvu fonduose, VII knyga (Vilnius, 2003), pp. 162-163.

321829 plan of Vilnius, LVIA, f. 526, ap. 3, b. 11, 1. 1. 
consisted of a two-storey (from the River Vilnia two-storey, from the Antakalnis side one storey) 72.5 by 10.6 by 4.97 -metre brick house covered with tiles. By the house were some wooden stables with stone pillars. ${ }^{33}$ The house was later adapted as a barracks. ${ }^{34}$ The third property (no 1353), a house with built-on premises, had to be demolished, because the defensive line had to be installed in its place. ${ }^{35}$ Some of the materials from the demolished building were used in the construction of the fortifications. The government of the guberniya obliged the city's Duma to look after the work of the demolition of the house at its own expense, and to prevent the theft of the building materials. ${ }^{36}$ At the more remote approaches to the fortifications of the Hill of Three Crosses there were still a few properties. On Sluškų (currently T. Kosciuškos) St, there was the Sluškai Palace and a large plot (no 1355) that belonged to Dominykas Zaikovskis. The huge house with outbuildings (stables, coach-houses) was to be adapted for military needs. In the first decade of the 1800 s, the city government adapted the brick houses of the remaining two properties nos 1356 and 1357, near Slušku St as Russian barracks. ${ }^{37}$ At the foot of the Hill of Three Crosses, on the right bank of the Vilnia, was property no 508, which consisted of several wooden buildings, a garden and a wax manufactory. In 1825, it was still standing, but abandoned, so the architect Karol Podczaszynski advised the rector of Vilnius University to carry out

${ }^{33}$ Sarcevičius, 'Dainų slėnio paslaptys', p. 78; Kurjer Litewski (1822), no. 134, (1826), no. 100, (1829), no. 71, (1831), no. 28; Drèma, Vilniaus namai, pp. 163-164. Inventory of 11 June 1831 of the houses located in the territory of the fortress of Vilnius, LVIA, f. 381, BS, 1831, b. 2556, 1 dalis, 1. 91-92; Detailed description of 27 January 1832 of the houses and other buildings located in the territory of the fortifications of Vilnius, LMAVB, f. 20-5194, 1. 1; List of the 1808 possessions of Vilnius, LVIA, f. 458, ap. 1, b. 720, 1. 16.

${ }^{34}$ Sliesoriūnas, Gedimino aikšté Vilniuje, p. 36; Letter of 24 March 1836 from the Vilnius district court to the Vilnius Duma, LVIA, f. 937 ap. 1, b. 1256, 1. 89.

${ }^{35}$ In the 1808 census it is indicated that the possession is empty. Ibid., 1. 16; Detailed description of 27 January 1832 of the houses and other buildings located in the territory of the fortifications of Vilnius, LMAVB, f. 20-5194, 1. 1; Drema, Dingęs Vilnius, p. 163; Sliesoriūnas, Gedimino aikštè Vilniuje, p. 27.

${ }^{36}$ The letter of 4 July 1831 from Vilnius Duma advisor K. Vener to the Vilnius Duma, LVIA, f. 937, ap. 1, b. 1373, 1. 3; Letter of 27 April 1832 to the Vilnius City Duma, ibid., 1. 121.

${ }^{37}$ Letters of 28 06, 03 07, 16181812 from the Vilnius civil governor Obreskov to the Vilnius city Duma, LVIA, f. 937, ap. 1, b. 1225, 1. 120-125, 130; Drèma, Vilniaus namai, pp. 170-171. 
swift repairs. ${ }^{38}$ Probably, the buildings did not hinder either the construction of the fortifications or their subsequent maintenance, since the property is not mentioned on the list of houses involved in the area of the construction. ${ }^{39}$ Thus, the first significant changes in the approaches to the Hill of Three Crosses are related to the reshaping of the urban space: the buildings and the spaces near them are adapted to the needs of the infrastructure of the fortifications.

We can view the next significant intervention in the Hill of Three Crosses to be the building of the fortifications of a defensive line. Ditches about 2.5 metres deep, reaching a width of 4.5 metres, surround this hill and its whole area. Behind them were parapets 4.11 metres high, and protective embankments 4.57 to 6.09 metres wide. From the drawings of the embankment, we can see that on the inner side of the parapet were tiers allowing soldiers to shoot over the parapet. The line of ditches and dykes around the hill was not continuous: from the pill-box to the approaches of the right bank of the Vilnia, the steep slopes of the hill, reaching about 50 metres in height, replaced it. ${ }^{40}$

The defensive line on the slope of the Hill of Three Crosses marks the place where during the time of the construction, the large-scale excavations that destroyed the original terrain of the hill's slopes were carried out. Another significant intervention in the former relief is linked to the installation in the ramparts of artillery guns in separate positions. They are constructed in such a way that there was sufficient space for the guns and the servicemen manning them. We can count five barbette ${ }^{41}$ cannons: the first at the corner of the Chodasevičius house in front of the River Neris, the second next to the house, only on the Antakalnis St side, the third on the slope of the Hill of Three Crosses, the fourth on the highest part of the hill, and the fifth in front of the defensive line on the slope of the hill, in a caponier/control post. The barbettes, based on the drawings, could be from five to ten square metres, except for the

${ }^{38}$ At the end of the 18th century the owner of the house was the architect Martynas Knakfusas. Later the possession returned to the ownership of Vilnius University. Drėma, Vilniaus namai, VI knyga, pp. 46-47; idem, Dingęs Vilnius, p. 43.

${ }^{39}$ List of 11 June 1831 houses, LVIA, f. 378, BS, 1831, b. 2556, 1 dalis, 1. 80-83.

${ }^{40}$ Drawing of the land fortifications of a section of the Hill of Three Crosses showing the dug down places. RVKIA, f. 349, ap. 1, b. 265.

${ }^{41}$ A barbette (en barbette) means a position in which the field cannon shoots above the parapet, and not through a porthole. This ensured a wider horizontal angle of shooting, but poor protection. 
one in the caponier. Military engineers had planned to accommodate ten guns of different types in the fortifications of the Hill of Three Crosses. ${ }^{42}$ However, the master plan in 1848 shows that in the fortifications of the Hill of Three Crosses, there were 11 artillery guns. In the first barbette a copper field cannon of six pounds was placed, designed to cover the main position from the right side of Antakalnis St to the left bank of the Neris. In the second barbette were two 24 pounders called karonados, ${ }^{43}$ designed to shoot in the direction of Antakalnis St. In the third a small-calibre (six pounds) field cannon was placed. On the hill were two 12-pound cannons. One of them was directed towards Castle Hill. They were able to fire at distant positions, like those on Bekešas Hill. ${ }^{44}$ The barbettes provided opportunities for the field cannons to have a wider horizontal shooting angle.

Perhaps the greatest military engineering structure on the Hill of Three Crosses was the caponier. ${ }^{45}$ It was installed not in the top, the highest, area of the hill, but on a lower terrace of trapezoid shape. It was raised separately from the main rampart, and connected to it by an underground passage, which in documents is called the gallery, with its own defensive line. It is obvious that during the installation of this structure, the old terrain was heavily affected. Positions in the caponier were made for two carronades, which were directed in different directions along the embankment. So this caponier occupied a unique position, because it had to ensure the flanking defence of the embankment. ${ }^{46}$ From here the artillery and infantry could easily fire on the area along the defensive wall, from the right up to the top of the Hill of Three Crosses, from the left to the positions of the nearest artillery cannons, as well as the

42 Description of the fortifications of Vilnius, RVKIA, f. 478, ap. 1, b. 7 , 1. $580-581$.

${ }^{43}$ A caronade was mostly used as artillery on ships, adapted for shooting a short distance. It was able to shoot projectiles and a canister shot, the effective firing range reached only about 250-300 metres. Usually from 12 to 42 pound calibre, it could be greater. Master plan of the fortifications of Vilnius in 1848, LVIA, f. 526, ap. 14, b. 564, 1. 1.

44 Ibid.

45 Fortification facility to shoot at the flanks in one or two directions. Until the 19th century it was installed in strongholds to shoot along fortress ditches. Enciklopedinis karybos, p. 233.

${ }^{46}$ Master plan of the fortifications of Vilnius in 1832, RVKIA, f. 349, ap. 8, b. $301,1.1$. 
space to the top of Table Hill. The area of this position may have been no less than 15 square metres.

In the general plan of 1848 , we can see that there was a concentrating place of the sixth artillery behind the defensive line, near the pill-box. Since the artillery pieces in it were positioned directly on the ground, without a specially equipped position along the defensive rampart, four 1.5-pood field mortars ${ }^{47}$ were concentrated here, aimed in the direction of the centre of the city. Mortars were used mainly as siege guns to destroy fortifications (for the siege of fortresses), as well as to fire at targets at which one could not fire with cannons, firing on a flat trajectory (e.g. soldiers hiding behind fortifications). Their use in the fortifications of the Hill of Three Crosses had a clear purpose - wide opportunities (for shooting targets perpendicular to the ground, called mortar trajectory) to shoot at not only the wide area on the left bank of the Vilnia, but in particular the more distant buildings in the city, because a mortar of such a calibre could not shoot a distance of more than one kilometre. ${ }^{48}$

We can state that an examination of the artillery layout schemes helped to reveal two important new elements: first, the places for the artillery positions, and particularly those in the caponier, were made through large-scale land management works, which significantly changed the former configuration of the terrain (works of land excavation or local or shipped earth put on the surface, seeking to accommodate in them the soldiers manning them); and second, the layout of the artillery shows how the garrison planned to fend off a possible attack by an opponent.

The next military construction objects directly related to the artillery positions, and also significant for the intervention into the terrain of the hill, are the 'little gunpowder cellars'. The words 'little cellar' indirectly show that the premises for storing gunpowder and projectiles were small, as was the method of their construction: buildings dug into the ground. On the Hill of Three Crosses, based on the general plan of the Vilnius fortifications in 1833, we

\footnotetext{
${ }^{47}$ A large-calibre cannon, shooting at ground targets with a very perpendicular trajectory.

48 Master plan of the fortifications of Vilnius in 1848, LVIA, f. 526, ap. 14, b. 564, 1. 1; Voenaia entsiklopediia, 16 (St Petersburg, 1911), p. 441; 36 artillery pieces of various types comprised the weaponry of the Vilnius fortifications. A description of the cannons, gun carriages and ammunition for the armaments of the fortifications of Vilnius, LVIA, 1831, BS, b. 2556b, 1 part, 1. 394.
} 
can count six small cellars. A separate cellar was assigned to each artillery position. ${ }^{49}$ Typical drawings of a gunpowder cellar of the Vilnius fortifications, in which the construction parameters of these buildings are fixed, confirm this, and that helps answer the question to what extent their construction work influenced the changes to the original terrain. Military engineers planned three types of little gunpowder cellar in the Vilnius fortifications. We find all three in our investigated object. First, by the walls of the Chodasevičius house marked with the number 12, was the smallest wooden building in the shape of a square. It had one storey, was partly dug into the ground, and in the middle of the facilities were dual L-shaped shelves along the walls and inside. The second type of small cellar was set up in the positions marked with the numbers 14, 16 and 17. According to their external and internal breakdown, these storage areas are almost identical, but slightly larger than the one labelled with the number 12. Judging by the location of their deployment, they were on the slope of the hill. It is known that Colonel Kapela, in the initial stage of the construction of the cellar, demanded that the city's Duma provide 25 labourers and eight wagons. ${ }^{50}$ Based on the scale of the mentioned drawing, we can calculate that the gunpowder cellars took up an area of six square metres. Later, near the mentioned cellars that could accommodate a minimum quantity of ammunition, spare gunpowder warehouses were built. The powder cellar marked with the number 15 was the largest, because it was for two artillery guns in the caponier. The builders installed this cellar beyond the line of the embankment, so a distance of dozens of metres separated it from the cannons. The basement drawings display a rectangular-shaped building, recessed into the ground, with a roof, covered with soil, and an entrance. Inside the building, along the walls and in the centre, there were three level sets of shelves. ${ }^{51}$ The walls of the little cellar were built of logs and boards. It filled a space 15 square metres in size.

${ }^{49}$ Master plan of the fortifications of Vilnius in 1833, RVKIA, f. 349, ap. 8, b. $301,1.1$.

${ }^{50}$ Colonel Kapela's letter of 6 October 1831, f. 378, 1831, 2556, I part, 1. 16.

${ }^{51}$ Detailed drawing of the little gunpowder cellars of the Vilnius fortifications, built in 1832, RVKIA, f. 349, ap. 8, b. 276, 1. 1; drawing of 26 April 1832 of wooden gunpowder cellar no. 15, ibid., b. 287, 1. 1; Master plan of the fortifications of Vilnius in 1833, ibid., b. 301. 
We should consider the pill-box built on the terrace of the second hill, in a downward square toward the side of the Neris, surrounded by a small ditch from the top of the Hill of Three Crosses, the central and largest building. The side of the pill-box building on the Vilnia side was not covered, because the steep slope of the hill began near here. From the drawing of the pill-box, we can see that it consisted of ten wooden buildings of various sizes. Judging from the description of the fortress, the premises of the pill-box had to accommodate some of the garrison, about 110 troops. $^{52}$ It fitted on to a 250-square-metre area of the hill. During the construction of the pill-box and the buildings, much land management work had to be carried out to prepare the site for the construction of the buildings, to dig out the foundations, and prepare a ditch. Bricks from the brick houses being torn down were used for the foundations of the pill-box buildings. Therefore, we can state that the terrain of the terrace during the construction of the fortifications changed depending on the purpose of the work. The premises of the pill-box stood practically empty, because it was used only for guarding, or to be more accurate, the guards from the Chodasevičus houses were directed to the pill-box. ${ }^{53}$

In summary, we can say that the greatest, clearly visible changes, testifying to the destruction of the cultural layer, were in the band of the defensive line, the sites of the little gunpowder cellars, the reserve gunpowder cellar and the caponier. True, we can also talk about the reverse phenomenon in the defensive line, when the cultural layer is covered with earth from the excavated trench. However, we are not sure about the pill-box building, because relying on historical sources, we can not accurately determine what kind of intervention (destruction, conservation or both) it was. On the other hand, we should bear in mind that in the construction works, large quantities

${ }^{52}$ Sliesoriūnas mentions that 1,100 troops fitted in the pill-box, clearly this is a typographical error, because such a huge number could not fit physically in the small spaces of the building even on the terrace. Sliesoriūnas, Gedimino aikšte Vilniuje, p. 20; Drawing of the pill-box in 1833, RVKIA, f. 349 , ap. 8, b. 302, 1. 1; Description of the fortifications of Vilnius, ibid., b. 478 , p. 1, b. 7, 1. 577; Letter of 8 August 1831 from Colonel Kapela to the temporary military governor of Vilnius and Grodno Chrapovicki, LVIA, 1831, BS, b. 2556, 1 part, 1. 395.

${ }^{53}$ Letter of 31 December 1832 from Vilnius Engineering Team Captain Semionov to the military governor of Vilnius Prince Dolgoruky, LVIA, f. 378, 1831, b. 2556, 1. 83-85; Sliesoriūnas, Gedimino aikštè Vilniuje, p. 37. 
of earth (not just turf) were brought from other locations in the city and its surroundings.

Minor changes were carried out in the infrastructure of the fortifications during the four decades of operation. During the first four years, there appeared in addition two new objects: 'a place for retreating near the pill-box', in the general plan of 1834, marked with the number 32, and a reserve gunpowder warehouse, marked with the number 35 . The first engineering structure was installed in front of the pill-box, on the River Neris side, at the foot of the hill. In the plan, a small-scale accommodation of which the purpose was to provide temporary shelter for a small number of soldiers was marked. ${ }^{54}$ We cannot identify its construction parameters precisely, due to the lack of data. But again, we can identify this place as the possible centre of the destruction of the cultural layer. The need for a reserve gunpowder warehouse arose due to the military's wish to have a larger amount of gunpowder and reserve shells. This building was built probably in 1834 , at the beginning of the central path leading from the main entrance to the fortifications by the bridge (at the mouth) of the Vilnia. The area of the warehouse was considerably larger than the above-mentioned gunpowder cellars. However, we failed to detect a detailed drawing of it, so it is difficult to determine accurately its dimensions. It should be assumed that this was a semi-underground building, as the military safety requirements for this kind of building were the same. ${ }^{55}$

In 1838 the defensive lines starting at the Chodasevičius house and continuing almost until the caponier were installed. ${ }^{56}$ The plan records a new supplementary ditch, and an embankment. In 1834 a wooden staircase was built on the Hill of Three Crosses so that it would be easier for soldiers to climb from the barracks to the post in the pill-box. In 1835, brick casemates were built in the yard of the Chodasevičius house, and three years later, wells were dug on both sides near the footbridge over the Vilnia. In 1839, a 'woven fence' was built on the Vilnia side, to accomplish a more practical

\footnotetext{
b. 313 .

${ }^{54}$ Master plan of the fortifications of Vilnius in 1834, RVKIA, f. 349, ap. 8,

${ }^{55}$ Master plan of the fortifications of Vilnius in 1835, ibid., b. 378; Fragment of the master plan of the fortifications of Vilnius in 1839, ibid., b. 463; plan of the fortifications of Vilnius in 1840, LVIA, f. 526, ap. 14, b. 570, 1. 1.

${ }^{56}$ Master plan of the fortifications of Vilnius in 1839, RVKIA, f. 349, ap. 8, b. 453 .
} 
task, to slow down the erosion of the steep slope. In the 1840 s, repair work of a minimal nature was done. In 1844 it was stated that the gunpowder cellars were damaged and required repairs, and also in the pill-box the newly installed platform for the sergeant's post, most likely the small room for those on duty. In the same year a new non-military element appeared in the territory of the fortifications in various places: lawns, which especially over the next three years spread both in the entire inner area and beyond. ${ }^{57}$

The huge flood in the spring of 1845 (the water level in the River Vilnia rose five metres) did not inflict any great damage to the fortifications of the Hill of Three Crosses, except that it washed away the little bridge over the Vilnia. In the same year, heavy rains, which damaged the embankments on the hill that had been abandoned for several years, caused greater damage. These examples show that natural erosion, such as the annual melting of the snow in the spring, acted constantly on the slopes of the Hill of Three Crosses. However, without doubt, the greatest impact should be attributed to human activities. In 1848, amid fears of possible unrest due to revolutionary events which began in Europe, the Russian government restored the abandoned embankments and ditches. From the middle of the 19th century, the fortifications operated for only two incomplete decades, during which no new large construction works were realised which could have had a significant effect on the changes in the terrain of the hill. The fortifications on the hill deteriorated rapidly, since they were not used or cared for. In 1857 the suspension bridge over the Vilnia became expendable, and two years later the wooden pill-box collapsed. Three years later, the same fate befell the underground gallery, and due to their poor condition, the caponiers had to be torn down.

Having lost their original purpose, the declining fortifications faced one more uprising in 1863-1864. In 1863, on the orders of the local government, first of all the ramparts and ditches were upgraded, and a wooden barracks was built on the Hill of Three Crosses, for the foundations of which 1,300 bricks from the foundations of the former pill-box were used. The building was not large, only 100 soldiers lived in it during the uprising. Two years later, the building

${ }^{57}$ Letter from the Vilnius commandant Lieutenant General Kusovnik, LMAVB, f. 20-5508, 1. 1-2; Master plan of the fortifications of Vilnius in 1848, LVIA, f. 526 , ap. 14 , b. 561 . 
was demolished, and the Hill of Three Crosses after several years was eliminated from the area of the Vilnius fortifications. ${ }^{58}$

The construction of the Vilnius fortifications influenced radical changes not only on the Hill of Three Crosses, but also in areas associated with it. In the process of the planning and construction of the fortifications, at Russia's highest political and military level, it was stated that the heights next to the Hill of Three Crosses hindered the proper use of artillery and an effective flank defence. ${ }^{59} \mathrm{In}$ the master plan of 1831 we can see two hills marked by letters to the right of the Antakalnis road: the first is in front of the Chodasevičius house, the second a little further, towards the Ss Peter and Paul's Church. From the report to the emperor, we can see that by the order of Colonel Kapela, the tops of two hills were levelled, digging off 5,200 cubic metres of earth. According to the author, 'it opened the territory and enabled the artillery to fire on Antak $\mathrm{St}$ '. ${ }^{60}$ It remains unclear exactly where the dug-up earth was used, the levelled area near the hills, or in other land magagement works both within the fortress and its approaches.

Available data indicates that during the operation of the fortifications, there were still a few interventions into these hills. For instance, the master plan drawn up in 1838 states that in 1836 the digging work near the Antakalnis road 'of two heights was completed'. True, in this case the plan only provides the coordinates of the heights, and there is no more detailed information in the explanations about the volume of work carried out. From the master plan of 1839, we learn that similar work in these areas was carried out in 1838, not showing the quantity of the dug-up land. ${ }^{61}$ In this case, we failed to determine exactly what is meant by old or new excavations. ${ }^{62}$ Thus, it remains unclear how much the terrain of the hill was influenced, although we can assume that these hills could have been lowered significantly so that the garrison could fire freely on the further and near approaches, being in front of the fortifications in part of Antakalnis St.

58 Sliesoriūnas, Gedimino aikštè Vilniuje, pp. 45, 47-49.

${ }^{59}$ Letter of 22 March 1832 to His Imperial Highness, LMAVB, f. 20-5184, 1. 4.

${ }^{60}$ Ibid, 1. 5; Master plan of the fortress of Vilnius, LMAVB, f. 229-963, 1. 1.

${ }^{61}$ Master plans of the fortifications of Vilnius in 1838 and 1839, RVKIA, f. 349 , ap. 8 , b. 431 .

62 Plans of the fortifications of Vilnius in 1844, 1845 and 1846, RVKIA, f. 349, ap. 8, b. 542, 628, 602 . 
The Russian government began to realise the problem of the height of Bekešas and Table Hill with respect to the fortifications of the Hill of Three Crosses, after construction, i.e. in 1832. In the comments of one of the soldiers of the garrison, written in 1831 about the fortress: 'The arising kurgan being a distance of 150 cubits in front of the dominant heights, the Hill of the Cross, with a small perimeter of 15 cubits and the possibility for the enemy to reach it, is especially complicated, although it would be useful to demolish it by the method of exploding.' 63 No doubt, one has in mind Bekešas Hill. As has already been mentioned, on Table Hill one failed to realise the fortifications foreseen in the project. But it began to be carried out, and in the initial phase of the work the hill was also dug down. In the master plan of 1831, both hills (Bekešas and Table) are singled out, and in the explanations this sentence is entered: 'According to the drawing approved by His Serene Highness, the heights marked with the letters $\mathrm{H}$ [p.s. Table] and $\mathrm{M}$ [p.s. Bekeš] were dug down.' We should assume that Major General M. Klimenko, who led the work, had to carry out the tsar's decree, but the construction was not completed on time.

After the construction of fortifications, it became clear that the cannons of the caponier, as in part also those in the positions above them at the top of the Hill of Three Crosses, were severely limited by the neighbouring heights, Bekešas and Table hills. According to calculations of the time, the Hill of Three Crosses rose about 167 metres above the level of the Vilnia. Therefore, this issue was again discussed at the highest level, with Tsar Nicolas I attending. In that year the land management related to the Hill of Three Crosses was finally planned and realised. It is known that it was planned to dig down the land from 1.7 to 2.5 metres depth from the hill 'in front of the Hill of Crosses', and that would correspond to Table Hill, up to 1,320 cubic fathoms, i.e. 13,200 cubic metres of land. It was also planned to lower somewhat, up to 223 cubic fathoms $(2,230$ cubic metres), 'the hill located on the right side of the caponier', and that would be consistent with Bekešas Hill. This was realised in 1832. The realisation of this work is fixed in the master plan of

${ }^{63}$ Letter of 25 April 1831 to Major General Klimenko, LMAVB, f. 20-5184, 1. 5. The comments of Captain Jakovlev about the fortifications of Vilnius, RVKIA, f. $322-1500,1.2$. 


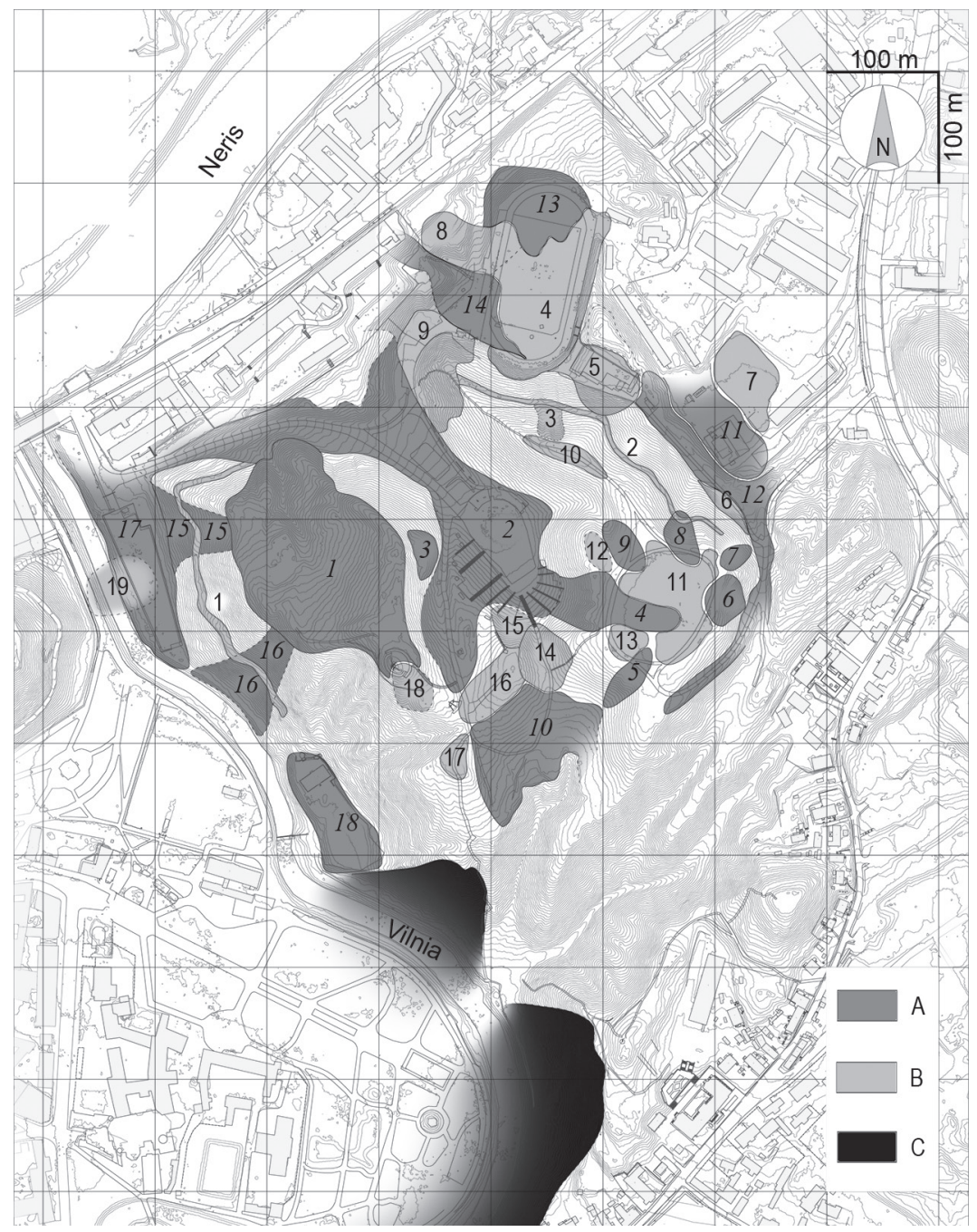

Fig. 2. Cartogram of the changes in the terrain on the current terrain (O. Valionienè) 
1833. ${ }^{64}$ So in this case we know the volume of the excavation of Bekešas and Table hills.

In 1846 the Engineering Department of the Ministry of War confirmed the project for the improvement of the Vilnius fortifications, according to which it was provided to realise work for the organisation of land exploitation one more time on Bekešas, the top and the southwest slope of the central hill, Table Hill and the northern ridge. ${ }^{65} \mathrm{We}$ did not find written data about the execution of these works, but in the master plan of 1899 , it is recorded that the height of the mentioned mountains was lowered several times (Fig. 2). ${ }^{66}$ The earth excavated on the top of Bekešas Hill was put on the southwest and northeast slopes. So, in this case, the cultural layer of the hill's top was completely destroyed, but it was preserved in the hill's slopes in the specified directions. In the case of Table Hill, there is a similar situation. The soil dug off the peak was put on the west, east and northeast slopes, and the peak (Fig. 2) of the northern ridge was reduced and widened. ${ }^{67}$ There is no doubt about the multiple invasions into the terrain of the mentioned hills and the northern ridge of Table Hill. We can boldly state that Table and Bekešas hills, at least according to historical sources, were lowered by at least two metres, while the perimeters of the summits grew larger, due to the earth deposited on the slopes.

${ }^{64}$ Letter to His Imperial Highness, LMAVB, f. 20-5184, 1. 4-5; Master plan of the fortifications of Vilnius in 1833, RVKIA, f. 349, ap. 8, b. 301, 1. 1.

${ }^{65}$ Master plans of the fortifications of Vilnius in 1846, LMAVB, f. 229-964.

${ }^{66}$ One should note that Russian soldiers made another plan, showing only the fortifications on the Hill of Three Crosses in 1899, more than a decade after the closure of the Vilnius fortifications. This plan is valuable because it provides in detail only the infrastructure of the objects of a military nature in the territory of Kalnu Parkas and captures the realised works from the very beginning of the inception of the Vilnius fortifications until their closing. This provides good opportunities to clarify the data recorded in the master plans. In this plan it is also stated about the multiple intervention in the reliefs of the mentioned heights, however again without specifying neither exact dates nor other important details. The master plan in 1899 of the gunpowder warehouses and the fortifications of the Mountain of Crosses, LMAVB, f. 229-968.

${ }^{67}$ Master plan of the gunpowder warehouse and the fortifications of the Hill of Three Crosses in 1899, LMAVB, f. 229-968. 


\section{The restoration of the paleorelief of the hills, based on cartographic, geological and geophysical methods}

The changes of the terrain that were identified according to historical data in many instances correlated with the investigations of the nature of the hills. Reconstructing the primary terrain of Kalnu parkas, by geological ${ }^{68}$ and geophysical ${ }^{69}$ methods, its common seven-hectare $\operatorname{area}^{70}$ (Fig. 1) was studied in 2008-2011. The Valley of Songs, Table, Bald (Three Crosses) hills and their mountain ridges, the northwest and in part the southern amphitheatres were studied. ${ }^{71}$ In the segment between the embassy of the Netherlands and the River Neris the right bank of the Vilnia was studied, as well as the territory to the northeast of Table Hill, in the former military town, now belonging to the War Museum. For the treatment of these data, cartographic sources were invoked, and for their interpretation, urbanistic methods. One should emphasise that only the complex application of different branches of science allowed us not only to bring to light the changes in the paleo-terrain of the investigated hills an to localise their places, but also to provide important arguments discussing the causes and dimensions of the changed landscape.

Hills were quite openly ignored. This is true not only of the earlier 17th and 18th-century plans, but even the first accurate plan of Vilnius, created in 1808 . We have to state that the accuracy of this

${ }^{68}$ The geologist Antanas Pečkaitis and archaeologist Sarcevičius conducted the geological investigations. In those places where the terrain prevented the use of geological investigations, geological boreholes were drilled at $10-30 \mathrm{~m}$ intervals. For the most part it was drilled until the geological earth. A total of 252 wells were drilled. In the northern amphitheatre (Am2, Valley of Songs) 75 wells were drilled (in 2008), on Table Hill, and on its ridges (K3 and K4) 87 wells (in 2009), on Bald Hill, on the middle ridge (K1) and the north-western amphitheatre (Am1) 39 wells (in 2010), on the southern amphitheater (Am3) 10 wells (in 2011), by the right bank of the Vilnia 23 wells (in 2010), and in the current territory of the War Museum 18 wells (in 2010). Drilling was carried out manually, with sets of drills from 100 to $30 \mathrm{~mm}$ in diameter.

${ }^{69} \mathrm{D}$. Michelevičius was in charge of the geophysical investigations. A total area of 3.17 hectares was investigated by geophysical methods.

70 This comprises about $32 \%$ of the area of the Crooked City-Castle, also including the slopes of the hills.

${ }^{71}$ Describing the microforms of the hills, we will use the names proposed by Vaitkevičius, such as southern (Am3), northern (Am2, current Valley of Songs), southwest (Am1) amphitheatres: southeast (K3), south (K4), middle (K1), west (K2) ridges. In the paleorelief the identified gullies are marked by the letter ' $R$ ', the heights 'Au' and the chine 'C'. See Fig. 3. 
hilly part of the city was clearly in doubt, because the landscape illustrated in the plans was not very similar to what existed (compare Fig. 1 and 4). This scepticism determined that researchers who wrote about the Crooked Castle in the best case relied on plans which were made after the establishment in 1831 of the Russian fortress in Kalnu Parkas. The latter plans of the fortress stood out by their accuracy. The terrain depicted in them corresponds to the current situation to the last detail. This is particularly clearly seen when we identify these plans with the current relief, which the digital terrain model of the surface (LIDAR) now reflects most accurately. ${ }^{72}$ This fact allowed us to make the rather unexpected conclusion that the current topography of Kalnų Parkas largely reflects the period of the 19th-century military fortifications. During the first year of the research, while processing the material from geophysicists and the geological drilling obtained in the northern amphitheatre (AM2), the similarity of the reconstructed original terrain with the views of the topography, marked in the 18th-19th century plans, was noticed. As the research continued, this careful observation became quite a strong provision that in the cartography of that period, the depicted forms of the terrain of the investigated hills also reflect systematically not the fantasies of an artist, but, even if schematic, the real topography of the hills. ${ }^{73}$ On the basis of the data obtained during the complex studies, a reconstruction (Fig. 3) of the paleorelief of the Crooked City was performed. Commenting on the changes in the terrain, we will discuss the main features in different parts of the hills.

Bald (Crooked, Three Crosses) Hill. Speaking about Bald Hill one has in mind not only its upper field (Au1), where the three crosses now stand, but also the two ridges - the middle (K1) and western (K2), and the area between them - the northwest amphitheatre (AM1). In the current topography, from the upper area (AU1)

${ }^{72}$ LADAR or LIDAR (Light Detection and Ranging), a laser scanning system from airplanes, which is used to make a digital model of the terrain of a locality. For more information see Z. Stankevičius, A. Kalantaitè, 'LIDAR žemès paviršiaus supaprastinimo algoritmų parametrų parinkimas, Geodezija ir kartografija', 2(35) (2009), pp. 44-49 or <http://old.vgtu.1t/upload/geod_zurn/44-49_gc_2009_2_ stankevicius.pdf $>$. The National Land Service under the Ministry of Agriculture furnished the spatial (LIDAR) data about the territory of Vilnius to the Lithuanian Institute of History.

${ }^{73}$ In this article we did not have possibilities to present all the analysed plans, so we will limit ourselves to the most accurate one, the Vilnius plan of 1808 . See Fig. 4. 
of Bald Hill going along the western ridge (K2), three descending terraces - areas - are revealed. ${ }^{74}$ In examining the 19th-century plans of the military fortifications, it was determined that practically the whole hill of Bald Hill and the ridges is a well-preserved architectual-landscape complex, reflecting the footsteps of military activity.

Geofiziniu The data of the geophysical and geological studies have helped to specify the extent of the changes that occurred in the 19th century. On the terrace of the western ridge (K2) of Bald Mountain was fixed a 2-6 meter thick cultural layer (Fig. 2, area of the filled up soil No. 1). The greater part of it consisted of filled up sediments - small and dusty sand. The uniform structure of these sediments testifies to the simultaneity of the fillings. After these fillings, above the geological earth was formed an up to $0.5 \mathrm{~m}$. thick cultural layer, in places with traces of distinct ashes and rotten wood. Radiocarbon studies showed that the age of the taken calibrated soil sample with $63.2 \%$ probability is the interval between 1150 to 1450 , so it certainly reflects the period of the Crooked Castle ${ }^{75}$. The filled homogeneous soil should belong to the period of the 19th c. fortress construction.

${ }^{74}$ The first terrace-square (drilling No 11-21) descends to $H_{\text {abs }} 146.5-142.00 \mathrm{~m}$. A $20-46 \mathrm{~m}$ wide and $23-33 \mathrm{~m}$ long square with a dominant $12^{\circ}$ slope to the north was investigated. In the west it rises to a $7-10 \mathrm{~m}$ wide rampart, behind which the western slope begins. The relative height of the slope to the River Vilnia is $57 \mathrm{~m}$.; the incline $30.2^{\circ}$. The second lower, square (drilling No 22-26) decreases to $\mathrm{H}_{\mathrm{abs}} 139.5-137.5 \mathrm{~m}$. A $50 \times 35 \mathrm{~m}$ area was investigated. The surface gradually flattens; however, the general slope of the surface in the northern direction reaches $1.7^{\circ}$. In the western part of the square there is also a $15.0 \mathrm{~m}$. wide elevation. From here the relative height to the west of the steep slope to the Vilnia is $52 \mathrm{~m}$, the slope $33.5^{\circ}$. The third, the lowest square (drilling No 27-30) decreases to $\mathrm{H}_{\mathrm{abs}}$ 130.50-128.00 $\mathrm{m}$. The surface of the square is more level, but with a slope to the north and east. The investigated $30.5 \times 25.0 \mathrm{~m}$ wide area is bordered on three sides by erosion slopes of varying relative heights. The relative height of the western slope up to the parking lot at the base reaches $40 \mathrm{~m}$, while the slope is $27.5^{\circ}$. The northern slope to the road to the Valley of Songs is on average $25.0 \mathrm{~m}$. high and has a slope of $27.5^{\circ}$. The surface of the eastern part of the square is limited by small erosive ravines and a slope with a relative height of 4.0-12.0 m. to the existing long gully (Au4).

${ }^{75}$ Bald Hill drilling No. 22, depth 3.7-3.94 m, soil with organic deposits and carbons. The research was conducted on 22 October to 24 November 2010 at the Radio-Isotopic Research Laboratory of the Nature Research Centre. Protocol of the C14 research No. RTL-125 stored in the archive of the Urban Research Departament of the Lithuanian Institute of History. 
After the building of the fortifications, not only the very top of the hill changed, but also the whole structure of Bald Hill and its continuing ridges. This is particularly evident when comparing the current situation to the plans in the late 18th and early 19th century, and even the drawings of the period. ${ }^{76}$ As has already been mentioned, in the plans, the western ridge (K2) does not always dominate, as it does now, but the middle one (K1). Moreover, next to the western ridge, there are still other heights ( $\mathrm{Au} \mathrm{2}$ ), which are north of and somewhat below the main area (Au1). These two heights are separated by a gully (R3). Two more large gullies (R1, R2) formed the heights Au3, and went down the slope, one towards the northern foot of Gediminas Hill, the other to the Sereikiškès side. Meanwhile, the gully in the northern part of the hill (R4), which is now dominant and by which one can enter the northwest amphitheatre, in the old plans is marked very faintly or not fixed at all. Instead, quite clearly portrayed is the terrace $(\mathrm{Au} 20)$ joining the northwest (Am1) and northern (Am2) amphitheatres. In the old plans, the visible relief microforms were confirmed by methods of geological and geophysical research. The installation of the 19thcentury fortress changed not only the top contours of the western ridge, changing the visual relationship of the western and middle ridges, but, most likely, in that period the two large gullies (R1, R2) sloping down in the direction of the Vilnia were filled in. For in the plans of the latter period, the silhouette of the western ridge coincides with the current one. ${ }^{77}$ Both geographical drilling ${ }^{78}$ and the LIDAR data prove the existence of these ravines. From the latter, we can see that traces of the gullies are perceptible in the current relief. Thanks to geological and geophysical investigations,

${ }^{76}$ In the research, two watercolours by Pranciškus Smuglevičius painted in 1785 were used. Drèma, Dingęs Vilnius, pp. 70, 124.

77 Chertezh Vilenskim ukrepleniem, 1831, RVKIA, f. 349, ap. 8, b. 259.

${ }^{78}$ Drilling No 2-5 of the bank of the Vilnia, drilling No 27-28 of Bald Hill. Drillings No 173, 178, 180 of earlier investigations. Data of the drillings taken from the report Gedimino kalno ir Katedros aikštès inžineriniai-geologiniai tyrinejjimai. I, II, III tomai. Techninis projektas. Vilnius, 1973, Inžinerinių tyrinėjimų institutas (UAB „Inžineriniai tyrinėjimai „,filialas“ „Inžineriniai geologiniai tyrinèjimai““”), komplekso Nr. 0061-1451; (A. Pečkaitis, S. Sarcevičius, Trijų Kryžių kalno aplinka, Trijų Kryžių kalno šlaito vakarinè papėdè (Vilnios upės žemupis), Vytauto Didžiojo karo muziejaus karo technikos filialas Vilniuje, Olandų g. Geologinių-archeologinių tyrimų ataskaita (Vilnius, 2011), p. 29. The file is stored in the Lithuanian Institute of History, departament of Urban research. 
the contours of the former hill (Au2), or more accurately the gully, separating the heights from the top area of Bald Hill (AU1), on which three crosses now stand, were found. The initial contour of the latter area, as well as the former elevation, also do not comply with the existing image. Here, the land was dug off. Measuring from the level of the River Neris at the inflow of the Vilnia, the initial investigations of the written and cartographic data indicate a height of about 265 feet or 38 fathoms. ${ }^{79}$ This would roughly correspond to Habs 168 m., ${ }^{80}$ while the current maximum height reaches Habs $165.10 \mathrm{~m}$. Knowing the former height of the upper area (Au1), the approximate slope of the area, the depth of the excavation ${ }^{81}$ and the maximum stable angle of the slope, which does not exceed 34 to 40 degrees, it is possible to reconstruct the original terrain of Bald Hill now in the location of the three standing crosses. It would turn out that the area (Au1) was about 18 metres $^{82}$ longer in a southeast direction (compare Figs. 3 and 4; also in Fig. 2 the area of the dug off earth no. 18). Sloping down in a northerly direction, it connects directly not only with the western (K2), but also with the middle (K1) ridge.

Summarising the data of the investigations of the middle ridge (K1) of Bald Hill ${ }^{83}$ it was noticed that the upper part of the ridge suffered the least from the 19th-century constructions. The thickness of the cultural layer here reaches 2.4 to three metres. In the explo-

79 Chast' generalnogo plana goroda Vilniusa, Paminklų restauravimo instituto archyvas-68.

${ }^{80}$ The explanations of the tetherings of the heights are reflected in the drawing 'Profili chiastiam Vilenskikh ykreplenii i vysoty raspolozhenii po pravuiu storony Antokolskoi dorogy oznachenikh na generalnom plane Vilenskikh ykreplenii', 1839, RVKIA, f. 349, ap. 8, b. 454.

${ }^{81}$ LIIA, f. 1, b. No. 1611, drawing No 3. Relying on these investigations, it was determined that in the 19th century it was dug down to $\mathrm{H}_{\mathrm{abs}} 162,68 \mathrm{~m}$.

82 Investigations in 2010 of Bald Hill drilling no. 6-10.

${ }^{83}$ The middle ridge is $110 \mathrm{~m}$. long (drillings of Bald Hill No 1-5). Its width is only $2.0-4.0 \mathrm{~m}$, and the surface decreases from $\mathrm{H}_{\mathrm{abs}} 162.00 \mathrm{~m}$ to $150.00 \mathrm{~m}$ (average slope $8^{\circ}$ ). From the end of the ridge (drilling No 5) in the northwest direction two lower triangular form areas were surveyed: by $\mathrm{H}_{\mathrm{abs}} 136.00 \mathrm{~m}$ (drilling 36) and $\mathrm{H}_{\mathrm{abs}} 126.00 \mathrm{~m}$ (drilling 37). From the ridge up to them, the overall slope is about $24.7^{\circ}$. The ridge and the two mentioned lower areas on three sides have slopes of various relative heights and inclination. The greatest relative heights on the southeast and northeast slopes reach $26.0-18.5 \mathrm{~m}$, the inclination of the slope varies $24-34^{\circ}$ range. The relative heights of the western slope to the gully $\mathrm{Au} 4$ is lower, and the inclination reaches $13-25^{\circ}$. 
red lower areas in the extension of the ridge, the thickness of the added cultural layer even reaches 4.5 metres. This shows that in the strengthening of the defence functions, the middle ridge at some stage was lengthened and widened in the direction of the River Neris. Although we cannot say anything about the chronology of these works, we can decide from radiocarbon (C14) dating about the period of the fortifications that were on the middle ridge. In the middle ridge, at a depth of 0.5 to 1.5 metres, there were fillings of clay up to two metres thick, definitely showing their defensive nature. The clay embankment stretched not only along the secondary ridge, but also continued to the western edge of the upper area (AU1). The clay ridge comprised two levels, which a layer of charred logs separated. Radiocarbon investigations of samples taken from this level gave a calibrated chronological interval from 1620 to $1820 \mathrm{~m} .{ }^{84}$ This shows that the top embankment of clay is not attributable to the period of the Crooked Castle, ${ }^{85}$ but to later fortifications, which are related to the wars that took place in the middle of the 17 th and 18 th centuries. Both historical sources ${ }^{86}$ and 18th-century cartographic data testify to the existence of such fortifications on Bald Hill. ${ }^{87}$ Fragments of clay ramparts are also detected on the western ridge (K2). Here they also decompose into two levels. The ramparts are felt in two drillings. One of them is

${ }^{84}$ Drilling of Bald Hill No 1, depth $1.83 \mathrm{~m}$, carbons. Investigations conducted on 22 October to 24 November 2010 at the Radio-Isotope Research Laboratory of the Nature Research Centre. Protocol of the $\mathrm{C}^{14}$ investigation No RTL-125, stored in the City Investigation archive of the LIH.

${ }^{85}$ V. Daugudis, S. Lasavickas, E. Kirdulienè, Vilniaus Plikojo (Trijų kryžių) kalno $1991 \mathrm{~m}$. archeologiniai tyrinejjimai, 1991, LIIA, fund of drawings, drawing No 12670-12691. Comparing the cuts of the latter research with the data of drillings Nos 1, 8 in 2010, we notice stratigraphic concurrences. This is especially true of the upper heights of the clay embankment excavated in 1991, and their thickness. The researchers themselves date the mound to 1390 , but no other data about the investigations apart from drawings and articles of a general nature have survived. V. Daugudis, 'Nauji duomenys apie Vilniaus Plikojo (Trijų Kryžių) kalno praeitį', Lietuvos mokslas, T. II (2-3), (1994), pp. 162-175.

86 E. Meilus, 'Vilniaus Pilių apsiaustis ir išvadavimas iš maskvènų (16601661 m.)', Vilniaus Žemutine pilis XIV a.-XIX a. pradžioje. 2005-2006 m. tyrimai, (Vilnius, 2007), p. 95.

${ }^{87}$ J. Liguz, 'Plan Wilna Georga Maxa von Fürstenhoffa jako źródło historyczne', Kartografia wojskowa krajów strefy baltyckiej XVI-XX w. Materiaty konferencji naukowej, Toruń, 20-22 października 1994 r., eds. S. Alexandrowicz, Z. Karpus, W. Rezmer (Toruń, 1996), pp. 81-83. 
found by the south (R2), ${ }^{88}$ and the other by the north (R1) ${ }^{89}$ wash. From the western end of the ridge, sloping down toward the Vilnia, parallel to the northern edge of the gully (R1), we can also visually discern the contours of an embankment from an unknown period. As we can see, not only the subgrading works that occurred in the 19th century, but also the construction of the 17th and 18th-century fortifications could have affected the terrain of the hills. However, due to a lack of data, there are so far no possibilities to determine their extent.

\section{Table Hill}

The current Table Hill consists of a flat field occupying an area of up to $1.3 \mathrm{ha}$, as well as the ridges of the hills extending from it, the northern (K3) and the southern (K4). ${ }^{90}$ The slopes are level, the only somewhat steep gully (R10) can be seen near the northern ridge (Fig. 3). In the 1950s, while installing the estrade of the Valley of Songs, the top of Table Hill was pulled down by bulldozers. ${ }^{91}$ As an analysis of the contemporary terrain and historical sources showed, up to when the construction of the fortress began in 1831, Table Hill along with the northern (K3) and southern (K4) ridges did not have a dominant plateau, and its form was more like a bow. Around the middle of Table Hill there was another central hill (Fig. 3; Au7,

${ }^{88}$ In 1968 drilling No 172. Two clay horizons are detected. The upper one is fixed at 3.8 to $4.2 \mathrm{~m}\left(\mathrm{H}_{\text {abs }} 145,08-144,68 \mathrm{~m}\right)$, the lower from 5.1 to $6.3 \mathrm{~m}$ $\left(\mathrm{H}_{\mathrm{abs}} 43,72-142,58 \mathrm{~m}\right)$. A. Pečkaitis, Vilniaus piliakalnis su papiliais. Geologiniai tyrimai (Vilnius, 2010). The manuscript is stored in the Departament of Urban Research of the Lithuanian Institute of History.

${ }^{89}$ Drilling No 22 of Bald Hill. Clay was detected at a depth of 1.8-3.1 m $\left(\mathrm{H}_{\mathrm{abs}}\right.$ 128,90-127,40 m). Two horizons are distinguished.

90 The current height of the Table Hill area is $\mathrm{H}_{\text {abs }} 163.00-164.50 \mathrm{~m}$. The slopes of the area are unequal in length, but steep. The relative heights of the slopes and gradients change as follows: west of the Valley of Songs 23.5-26.5 m

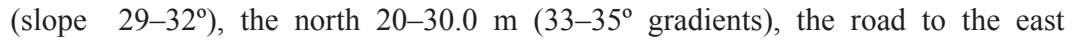
$15.5 \mathrm{~m}\left(25.5^{\circ}\right.$ inclination). The length of the upper part of the northern ridge is $115 \mathrm{~m}$; the width 10-12 metres (area $0.13 \mathrm{ha}$ ). From $\mathrm{H}_{\mathrm{abs}} 160$ the altitude of this ridge in the northeast from $149.0 \mathrm{~m}$ lowers to $\mathrm{H}_{\mathrm{abs}} 123$ metres (the incline of the western slope is $27.5^{\circ}$ ). The relative difference of the heights of the southern slope of the ridge is about $27 \mathrm{~m}$. (slope $24.5^{\circ}$ ), of the north $47 \mathrm{~m}$ (slope $38^{\circ}$ ). The length of the southern ridge in the south-north direction is $41.0 \mathrm{~m}$, the width $21.0 \mathrm{~m}$ (area $0.09 \mathrm{ha}$ ). Particularly long, reaching $230 \mathrm{~m}$, is the southern slope of the mountain ridge, the relative difference in height is $66.0 \mathrm{~m}$, average slope $31^{\circ}$.

${ }^{91}$ LIIA, f. 1, b. 40, p. 1. 
Au10), which a great gully (R5) separated from Table Hill. This central hill restricted the northern amphitheatre (AU2) from the southern (AU3), while its other end was around the main area of Table Hill, which was separated from the latter by the gully (R11). In 1832 it was planned to dig down the entire area of Table Hill to 1.5 to 4.2 metres (Fig. 2 areas of the excavated land no 11-13). In 1842, the height of the area of Table Hill reached around Habs $165.50 \mathrm{~m} .{ }^{92}$ Hence, before the start of the land excavation work, the greatest height of the mountain in the eastern part of the hill had to be no less than Habs 168.50 to $169 \mathrm{~m}$. (Au5). From this point in different directions extended gullies of various size and depth. The contours of some of them (R10, R7, R8) are seen in the current LIDAR terrain model. The contours of others were revealed by investigating the mountain by geological and geophysical methods.

Three washes (R7, R8, R9, also Fig. 2, the plots of the poured soil no. 6-8) were carved into the heights (Au5) of Table Hill from the east. Two of them (R7, R8) went down to the gully (R16) surrounding Table Hill on the south, and one (R9) went down towards the gully (R20), framing the hill on the east side. The central great gully was found by geological and geophysical studies (R5; Fig. 2, area of the poured soil no 4). With geo-radar we were able to grasp even the part of the site where the original surface was excavated one to two metres. In the geomagnetic profiles, we can see that the existing geological layers lie approximately parallel to the deflection of the remaining fragment of the primary relief. This allows us to get an impression of the shape of the excavated part and the former elevations. A gully (R5) extended from Table Hill towards the northern amphitheatre (Am2). A gully extending to the heights (Au5) was ploughed into the area of Table Hill, dividing it into two parts, the northern (Au5) and southern (Au6) heights. They became respectively the northern (K3) and southern (K4) parts of the ridges. The contours of another gully (R6, also Fig. 2, the plots of the poured soil no 5) were fixed in the southwest part of the area of Table Hill. Both of these gullies (R5, 6) separated part of the current Table Hill from the main Table Hill, which in this way acquires the shape (Fig. 4) of an arc visible in old cartography. Meanwhile, the separated part of the heights $(\mathrm{Au} 7)$ at the chine merges with the current elevation (Au10), forming a separate part

92 Generalny plan Vilenskykh ukreplenii, 1842, RVKIA, f. 349, ap. 8, b. 526. 
of the hills, the central hill. After reconstructing the re-dredging location between Table Hill and the central hill, it turned out that the height of the chine could reach Habs 155 m. (Fig. 2, areas of the excavated land no 14). In the arising ravine there is now an asphalt road connecting the estrade with the southern amphitheatre (Am3). After checking the soil from this place with geological boreholes, it was discovered that there was no cultural layer; this confirmed the hypothesis about its excavation.

During the reconstruction of the relief, the highlighted Central hill (Au7, Au10, B2) in the period of the Crooked Castle had to play an important role in its defence. The fortifications built in this place had to defend the main roads that connected the northern and southern amphitheatres. Two road axes, going along the washes, became clear. The first surrounds the Central hill on the east side (R5, R6). Through these ravines one could also access the heights (Au5, Au6) of Table Hill. The other axis from the northern amphitheatre deviates towards the western end of the Central hill. At this point, the Central hill was separated from Bald and Bekešas hills by an entire network of gullies. One of them (R11) went down towards the northern amphitheatre (Am2), the other (R12) in the direction of the southern amphitheatre (Am3), and the third (R13) towards the River Vilnia. It seems that at the point of intersection of these washes, there was a watershed, the chine (B3). Historical records testify that the chine was dug out during the building of the Russian fortress (Fig. 2). Our existing borehole data shows that the initial height did not exceed altitudes of Habs $151-152 \mathrm{~m}^{93}$. At the ends of the Central hills, the road junctions formed take on a very important strategic significance. Although the data of the reconstructed terrain does not allow us to directly connect the Central hills with Bald or Table hills, they had to connect at the junctions in a functional (defensive, communication) sense. The natural terrain determined that the road junctions were defended not only from the Central hill, but also from the heights of Table, Bald and Bekešas hills (Au5, Au6, Au1, Au11).

Significant changes to the terrain are observed not only in the current area of Table Hill, but also on the northern ridge (K3). The northern cape of the ridge was excavated for military reasons, shorte-

${ }^{93}$ In drilling No 33 of Bald Hill a cultural layer, the pad of which was $\mathrm{H}_{\text {abs }} 152,43 \mathrm{~m}$, was found, while in drilling no. $31 \mathrm{H}_{\mathrm{abs}}$ 148,60-148,65 m diagonally sinking greyish earth. The skewing of the layer indicates that there was a wash here. 
ning the ridge by 75 metres (compare Figs. 1 and 3, as well as Fig. 2 , the area of the excavated land No. 9). In places, the remaining area (Au9) of the ridge (Fig. 2, plot of excavated land No. 10) was also levelled. Where these works were not carried out, we can find polaster of burnt-out clay, proving that on the northern ridge of Table Hill there were buildings from the period of the Crooked Castle.

\section{The Valley of Songs}

In the area of the Valley of Songs, the northern amphitheatre (Am2), two naturally formed gullies were discovered. One of them stretched on the slopes (Fig. 3) of Bald Hill (R21), and the other (R22) on the north ridge of Table Hill (K3). The bottom of the latter is at present at about a depth of five metres. It was determined that the gully (R21) located near Bald Hill had been watery. It was still marked in the plans of the hills in the first half of the 19th century. The water from a spring flowing in it was marked as a small river which flowed into the River Neris in about the region of the current T. Kosciuškos St. The left bank of the River Neris at the time was much closer to the slope of Bald Hill, and only in the period of the 18th to the 20th century after fillings did it acquire its current look. At the confluence of the River Neris and the nameless stream, archaeologists in 1996-1997 discovered 14th-century fortifications, wooden frames with which the rampart was strengthened (Fig. 1). This was the first defensive barrier of the Crooked City on this side of the Neris. However, it was not the only one. Geological and geophysical data highlighted the existence of a fairly complex terrain in the Valley of Songs, between our already-mentioned washes. It consisted of three descending areas, terraces, in the direction of the Neris. ${ }^{94}$ The width of the areas reached 45 to 60 metres. Slopes of three to eight metres like terrace steps separated the areas from each other. Wooden buildings were built on the areas of the terraces. This is confirmed by data from archaeological studies in 1956, as well as the anomalies of geometric forms emerging at a depth of three metres detected by geophysical surveys on the largest, top terrace. However, it is likely that the terraces also had a defensive nature.

94 They are located at these altitudes: a) by the southernmost $40 \mathrm{~m}$ long area at $\left.\mathrm{H}_{\mathrm{abs}} 130 \mathrm{~m}, \mathrm{~b}\right)$ by the $80 \mathrm{~m}$ long area at $\mathrm{H}_{\mathrm{abs}} 124-126 \mathrm{~m}, \mathrm{c}$ ) at the $25 \mathrm{~m}$ long area at $\mathrm{H}_{\mathrm{abs}} 119-120 \mathrm{~m}$. 


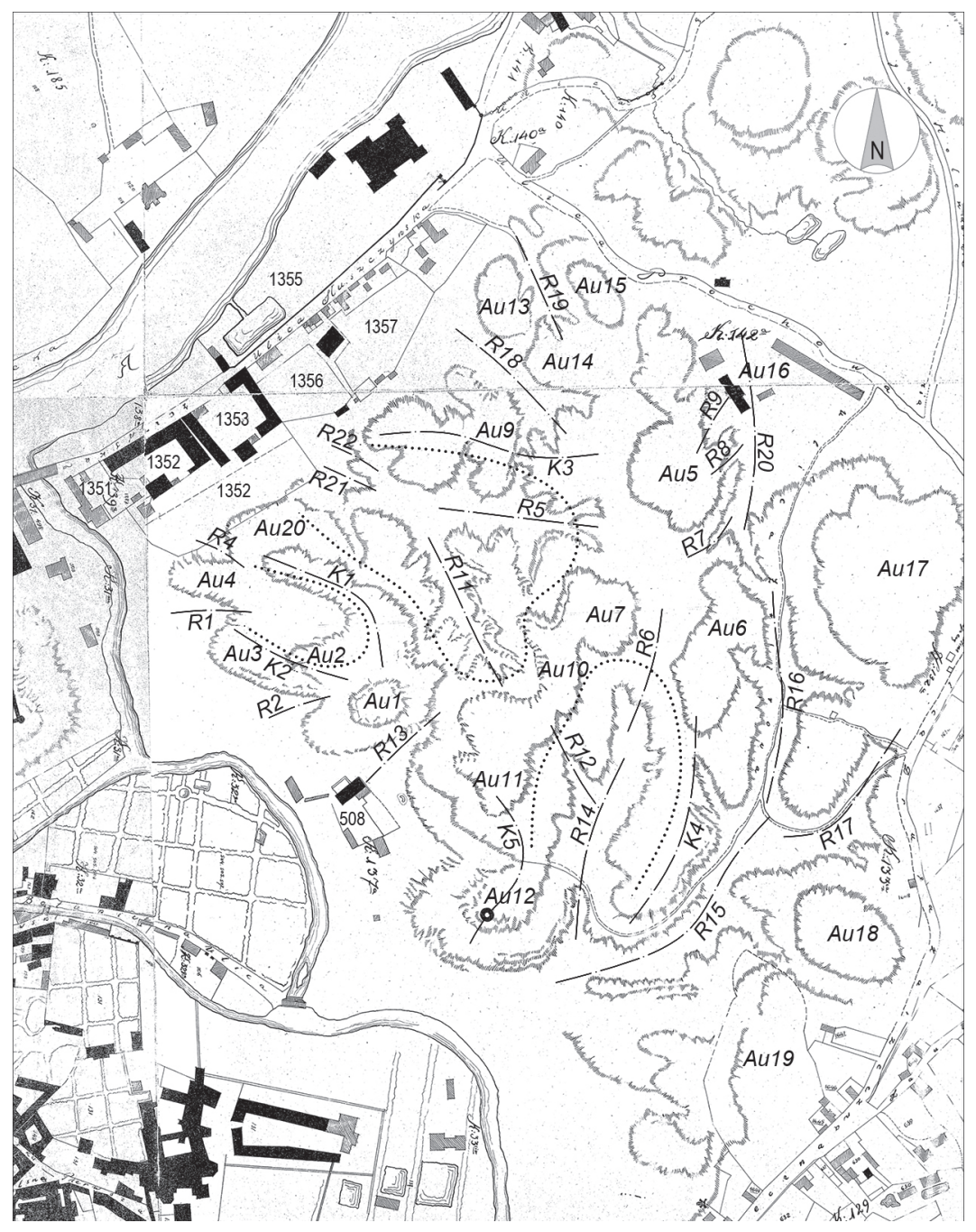

Fig. 4. Detail of a Vilnius map from 1808. For Legend, see Fig. 3 
By placing sharp stakes on their fringes, the defensive capacity of the castle increases significantly on the most accessible northern side. The assaults on the main castle in 1390 and 1394, when the Teutonic Knights attacked it, also took place from this direction.

Research on the Valley of Songs showed that during the period of the Crooked Castle, the upper terrace in the east-west direction was wider than the current estrade. The area of the terrace decreased thanks to large fillings on the west side, where the western grandstands are now. The thickness of the bulking here reaches up to seven metres. Only in the area bounded by the drillings has a quite impressive 20,280-cubic-metre mound of earth formed. We should draw attention to the fact that the earth used for the filling was not brought from elsewhere, it was most likely dug on the spot. This would mean that the current terrain of hills located between Bald and Table hills is significantly changed. The chronology of the filling is not clear. Probably it is related to the 19th-century construction of the fortress, in particular with the not fully implemented project of the construction of the pill-box and the underground passage, by which the fortifications of Table Hill would have merged with those on Castle Hill.

\section{The southern amphitheatre (Am3)}

So far we can restore this area only approximately, there is insufficient data for a detailed reconstruction. From the seven investigated geological drillings, one archaeological hole ${ }^{95}$ and one archaeological area, ${ }^{96}$ we can decide that the primary relief here was damaged considerably less than in other parts of the hills. In almost all the drillings beneath the added earth 1.5 to 4.2 metres deep is the cultural layer, in the western part of the amphitheatre there was bright ash in it. The earth above this layer for the greater part is not the result of natural erosion, but appeared here at the time of the establishment of the Russian fortress, digging down the neighbouring hills, Bekešas and the central hill. It also appeared that the earlier area suitable for living was wider in the direction of Bekešas Hill (Au11) and the central hill (Au10). The average slope of the area was $10^{\circ}$, and the total area at least 1.3 hectares.

${ }^{95}$ LIIA, f. 1, b. 2099.

${ }^{96}$ Investigations by E. and V. Golubovich, 'Krivoi gorod Vilno', pp. 114-126. 
It should be assumed that the area could have been even larger. In the reconstruction, the scale of the erosion of the great washes (R14, R16) remained unevaluated, as the data was insufficient. There is also no information about the water resources, but it is likely that the population of this part could have used the source in the area of the Valley of Songs.

\section{The western slope of the hills and their base}

The River Vilnia is an important factor in the changes to the terrain of the hills. In earlier publications ${ }^{97}$ it was rightly stated that the Vilnia influenced the erosion of the slopes by the top area (Au1) of Bald Hill, where a considerable part of it had slid down to the Vilnia by the current Embassy of the Netherlands. ${ }^{98}$ However, the most striking examples are the landslips (Au12), fixed in written sources, of Bekešas Hill into the eroding river. We will note an interesting coincidence that the erosion of the hill increased when the fortress emerged. This is hardly a coincidence. The impression is that until the 19th century the slopes of the hills were quite stable. M. Łowmianska, writing about Sereikiškes, mentions that this suburb had occupied not only the area of the current botanical garden, but also the right bank of the Vilnia, in the section between Bald and Bekešas hills. And this area, according to the author, was densely built-up. ${ }^{99}$ By the way, the drillings made on the right bank of the Vilnia also illustrate this statement. Here, the thickness of the cultural layer reaches 4.5 metres. Hence, if the right bank was also densely built up, then its inhabitants did not see a great danger from the side of the hills. Most likely, the later influence of the erosion by the river of the slopes of Bald and Bekešas hills is closely related to the human factor.

We cannot define precisely the old river bed of the Vilnia, and how it changed in the course of time, but a few conclusions arise

97 Vaitkevičius, İžanginès mintys, p. 37.

98 The investigations in 2010 showed that the riverbed in the vicinity of the Dutch Embassy had come closer than it is now. Drilling No 22 on the right bank of the Vilnia, investigations in 2010.

${ }^{99}$ M. Łowmiańska, Wilno przed najazdem moskiewskim 1655 roku (Wilno, 1929). 
from what was published. ${ }^{100}$ First, the strength of the flow of the River Vilnia was regulated by dams, dykes and a system of canals. And it seems that this was done from the very beginning of the city's founding, because this aspect is closely related to the defence of the castles. ${ }^{101}$ The River Vilnia was important for defence in the wars of the middle of the 17 th century. ${ }^{102}$ The essence of this scheme is to release the water of the Vilnia at the right time by the dug channels which surrounded the stone walls of the castles. The viability of the channel system depended on the dykes, with the help of which the flow of water was regulated. The channels could have been buried and newly dug, according to defence or other needs, but the places of the dykes changed much less frequently. Thus, from a military point of view, for the defenders of the castle, the dykes became an important defence object. They are still protected for one more simple reason: where there is a dam a road usually arises, which becomes an important artery of the city. ${ }^{103}$ Judging from later sources, one of the dams was near Bekešas Hill. ${ }^{104}$ It was called a gateway, and was needed to regulate the flow of water, to maintain the necessary level of water in the moat that surrounded the citadel. It may be

100 J. Jurkštas, Senojo Vilniaus vandenys (Vilnius, 1990); idem, Vilniaus vandenys, Istoriniai tyrimai (Vilnius, 1973), PRI archyvas F5-873; A. Kirkor, Istorikostatisticheskie ocherki Vilna, p. 78; J. Kurczewski, Koscioł zamkowy czyli katedra Wileńska, 1-3 (Wilno, 1909-1916).

${ }^{101}$ In this context, it is worth recalling the episode of the attack on Vilnius in 1394, when the Teutonic Knights, having captured the Crooked Castle, and starting the assault on the Lower Castle, encountered a serious, and as it turned out, an insurmountable obstacle: the dams encircling the castle walls. They tried to lower the water by digging a moat, but after suffering many casualties, abandoned the idea (Scriptores rerum Prussicarum, 2 [Leipzig, 1861-1866], pp. 658-660).

102 Kurczewski has published a stack of documents from the acts of the capitula, in which there are hints about the management of the bed of the Vilnia: 'during the time of the 1655-1661 war and occupation of the city, Moscow's army for defence purposes had changed the bed of the Vilnia [only it is unclear where] and dug new channels [near the castle], which were flooded so that it would be easier to defend the captured castle' (p. 34). It is also written 'in 1667 the Seimas decided to regulate the bed of the Vilnia and to liquidate the channels near the castle' because 'it was a tenuous thing, since the wooden fortifications of the banks of the canals and the dams during several years became rotten'.

${ }^{103}$ L. Karalius,'Tiltai, pervažiuojamieji perkolai, kamšos, pagrandos, mediniai grindiniai, pylimai Lietuvos Didžiosios Kunigaikštystės sausumos keliuose XVI amžiuje', Lietuvos istorijos metraštis, 2008/1 (2009), p. 20.

104 J. Jurkštas, Vilniaus vandenys. Id. Istoriniai tyrimai (Vilnius, 1973), PRI archyvas F5-873, p. 60. 
that the place has not changed from the times of the existence of the Crooked City, while the fortifications on Bekešas Hill (Au11-12) had a very important defensive role in protecting access to the dyke. In this way, until the middle of the 19th century, the flow of the river was controlled by hydroengineering structures, which began to be abandoned in the second half of the century. A consequence of the demolished mills, filled ponds and dismembered dams was that the Vilnia became much faster, and quickly began to erode the right bank. ${ }^{105}$ Thus, the eroding effect of the river's water on the slopes of Bald and Bekešas hills is closely related to the human factor. For the landslip of Bekešas Hill, by the way, the blasting works on this hill which were carried out here in the 1830s did not play the last role. At the same time the remaining part of Bekešas Hill ${ }^{106}$ (Au11, also Fig. 2, B1, also Fig. 2, harvested area of soil No. 19) was also excavated, and the excavated soil was most likely deposited on the southern amphitheatre (Am3).

The excavation works of the river bed of the Vilnia on the section between Gediminas and Bald hills had an impact on the stability of the slopes. These works must have been carried out in the 14th century. In the opinion of geologists and geo-morphologists, there was a chine in this place in the past. E. Vodzinskas in 1960 expressed the idea that it had been at the curve of the old river bed of the Vilnia, on the southern side of the eastern slope of Gediminas Hill. ${ }^{107}$ According to him, the juncture was the lowest point of the chine, which was about 20 metres above the current level of the Vilnia, which is about 106 metres above sea level. The geologist Rimante Guobyte presented the version that this link was closer to the Neris, on the north side of the east slope of Gediminas Hill. ${ }^{108}$ In our view, the most logical place for the juncture (B1) is between the two washes (R1, R2) through which the distribution of the surface water took place, and the very juncture was the line of its watershed (Fig. 3). An additional argument is that at this point the

105 Ibid., p. 69.

106 The current height of the hill is $\mathrm{H}_{\text {abs }} 152 \mathrm{~m}$. In the reconstruction of the paleorelief, the height of this part of Bekešas at $\mathrm{H}_{\text {abs }} 154 \mathrm{~m}$.

${ }^{107}$ E. Vodzinskas, 'Vilniaus miesto Gedimino kalno geologiniai ir geomorfologiniai bruožai', Lietuvos TSR geografine draugija. Geografinis metraštis, 3 (1960), pp. 120-121.

${ }^{108}$ R. Guobyte, 'Vilniaus pilių teritorijos egzotiškasis reljefas ir gelmių sandara', Lietuvos pilys, 3 (2007), p. 30. 
horizon of the moraine loam, which had to block the flow of the Vilnia, is the highest compared with the adjacent environment. ${ }^{109}$ The altitude of the loam is approximately four metres above the channel alluvium pad of the Vilnia. ${ }^{110}$ This proves the existence in this place of a chine (B1, also Fig. 2, area of the excavated soil No. 19). After excavating it, the river water was released through natural ditches, which also influenced the 'curving' of the newly excavated bed of the Vilnia recorded on old maps (Fig. 4). From the point of view of urban development and defence, the existence of the juncture is an important fact in explaining the necessity of the excavation of the new riverbed of the Vilnia, the conditions for communication between separate parts of the early city, the Lower and Crooked Castle.

\section{Changes in the terrain east of Table Hill}

As we can see, in the past, the terrain of the Crooked City differed significantly from the current one. However, it is completely and unrecognisably changed to the east of Table Hill, in the direction of Antakalnis. The reconstruction of the paleorelief of this territory requires a separate study, so we will only mention in our article the changes to the terrain at the eastern foot of Table Hill. First of all, there is the significantly changed terrain in the location of the current 'Dynamo' stadium, built in the interwar period. Today, it is a solid plateau, adjoining the northern ridge of Table Hill at an

109 The top loam is the highest on the right bank of the Vilnia at drilling No 12 $\mathrm{H}_{\text {abs }} 90,40 \mathrm{~m}$, while at drilling No 13, located $40 \mathrm{~m}$ further south $\mathrm{H}_{\text {abs }} 89,38 \mathrm{~m}$., while at drilling No 17, this layer was not reached. At drilling No 6, located $60 \mathrm{~m}$ north of drilling No 12, the horizon of the moraine loam is also downward. Here it is reached at $\mathrm{H}_{\text {abs }} 87.32 \mathrm{~m}$.

110 At the mouth of the River Vilnia no geological drillings were made at the bottom of the Neris, so we do not know about the depth of its incision. To the west of the Lithuanian Academy of Sciences Library there is drilling data: the alluvium sole of the Neris bed was fixed at $\mathrm{H}_{\mathrm{abs}} 81.00 \mathrm{~m}$. At the current inflow of the Vilnia into the Neris, the latter's geological incision should reach about $\mathrm{H}_{\mathrm{abs}} 82.00-82.50 \mathrm{~m}$. Therefore, the sole (the depth of the incision) of the alluvial formations of the current bed of the Vilnia should be oriented to the incision of the Neris. Geological drillings (drillings No 256, 356, 456) show higher altitudes of the sole of the alluvial bed $\left(\mathrm{H}_{\mathrm{abs}} 85.68-86.03 \mathrm{~m}\right.$.) and that is more like a new bed of the river. The altitude of the sole of the alluvial bed of drilling No $1 \mathrm{M}-71 \mathrm{H}_{\mathrm{abs}} 83.28 \mathrm{~m}$ shows the former left bank of the Neris. The altitude of drilling No 657 of the sole of the alluvial bed being at $\mathrm{H}_{\text {abs }} 84.66 \mathrm{~m}$ shows the oldest place of the bed of the Vilnia. Pečkaitis, Vilniaus piliakalnis su papiliais. Geologiniai tyrimai (Vilnius, 2010), p. 7. 
altitude of Habs $122 \mathrm{~m}$. (Fig. 1). We must assume that this part of the hills began to be excavated at the end of the 17th century, while building the Sluškai Palace. ${ }^{111}$ An even greater invasion was carried out during the installation of the Russian fortress. The need to increase the firing angle of the cannons built on the slope of the central ridge of Bald Hill determined the levelling of the territory. In the restored relief of this part of the hills (Fig. 3) we see that in the past it consisted of three heights (Au13-15). Two of them (Au13, 14) connected the chine (B4). A deep gully (R18) separated the ridge (K3) from the heights (Au13, 14). Its pad, reaching the River Neris, widens considerably, creating a watery hollow which flooded when the river was high, in which the Sluškai Palace (Fig. 1) was built. ${ }^{112}$ The southern end of the gully meets the lower pitch of the heights (Au14), the chine (B5). South of this watershed a smaller gully (R24) is visible, which sloped down to another wide gully (R20) adjoining the eastern slope of Table Hill. Geological studies made in the site of the gully (R20) revealed that a cultural layer formed here from 1.5 to four metres thick. The greater part of it appeared in the 19th and 20th centuries, leveling the territory and

111 J. Valužyte, Pastatai T. Kosciuškos g. nr. 10, 12. Istoriniai tyrimai. In 2000 PRI, f. 5, b. 7583. Historical sources mention that Dominykas Sluška in 1691-1694 built the palace on a filled in peninsula. The peninsula was made by excavating the hill separating Antakalnis from the city (p. 4). The inscription written on the facade of the palace pompously testifies to these excavations: 'Conquerer of the elements, having suppressed the flow of the Neris and pushed aside the nearby mountains [emphasis by the author of the article], by himself, without the help of others, as if a new mountain arose in the air'.

112 The water of the overflowing Neris during the building of the Sluškai Palace reached the raised surface of the yard, significantly eroding the foundations of the palace. For information see B.R. Vitkauskienè, Duomenys apie Sluškų rūmus Vilniuje, Warsaw's Archive of Old Acts, PRI, f. 5, b. 7868, p. 10. The material from archeological investigations shows that in the place of the depression above the earth up to a $0.3-0.5 \mathrm{~m}$ thick layer of peat formed, showing that place was waterlogged. The top of the peat is fixed at an altitude of $H_{a b s} 90,90-91,30 \mathrm{~m}$. L. Girlevičius, Vilniaus senojo miesto su priemiesčiais ir urbanistineje teritorijoje (S. Daukanto a. 1A, Gaono g. 8, Kosciuškos g. 10, 12, Kreivasis skg. 6, Pylimo g. 19, Šv. Stepono g. 27, A. Strazdelio g. 1, Zarasų ir Paplaujos g.), an account of the archaeological explorations conducted in 2007, LIIA, f. 1, b. 4911, pp. 72-102; R. Jonaitis, I. Kaplūnaite, Žvalgomieji tyrinèjimai ir žvalgymai T. Kosciuškos g. 10-12, Archeologiniai tyrinejimai Lietuvoje 2008 metais. In the period 2004-2005, according to data from stationary observations, the level of the River Neris at the inflow of the Vilnia changed in the range of $\mathrm{H}_{\text {abs }} 86.69-88.70 \mathrm{~m}$. The maximum level of the Neris was fixed in the spring of 1931, when the water level by the inflow of the Vilnia reached $\mathrm{H}_{\mathrm{abs}} 93.00 \mathrm{~m}$. 
at the same time digging down the former hillock (Au16; Fig. 2, area of the excavated soil No. 7). Over the subsoil a cultural layer formed up to 0.2 metres thick. In it artefacts have been detected characterising the activities of people: the site of a fire, animal bones and released derivatives of geometric shapes in the schemes of geomagnetic anomalies, that could be linked to the period of the Crooked Castle. The network of gullies (R 15, 16, 18, 20) beyond the defence enclosure of the Crooked Castle would confirm this assumption. The arrangement of the gullies is very important in determining the location of the old roads. Their locations would show that in the 13th and 14th centuries the road towards St Peter and Paul's Church was not on the current Kosciuškos St, but, skirting the hilly terrain, going along the larger gullies (R 18, 20). The direction of Kosciuškos St, although it was the straightest, had a fundamental flaw - its path was blocked by deep and wide ravines, stretching from the hills towards the River Neris. One of them has already been mentioned (R18). But this was not the only one. In the section between this ravine and the current Antakalnis roundabout at least three more ravines are marked in old plans. Thus the relief was inconvenient for traffic going along the left bank of the Neris. The hilly locality cut by ravines was also not favourable for settlement. The area between the river's left bank up to Kosciuškos St and from Kosciuškos St 3 until the Antakalnis roundabout was not inhabited before the end of the 16th century, and these were only individual cases. ${ }^{113}$ The overall situation shows that the greater part of the obstruction is related to the 18th and early 19th century. ${ }^{114}$ In this way, as regards traffic, a much more convenient topography

113 Girlevičius, Vilniaus senojo miesto su priemiesčiais, pp. 72-102; Jonaitis, Kaplūnaite, Žvalgomieji tyrinejjimai ir žvalgymai, pp. 402-404; R. Jarockis, Lietuvių kalbos instituto lituanistikos fondų saugyklos sklypo Vilniuje, Vileišio ir Atkrantės g-vių kampe, 1990 m. žvalgomųjų archeologinių tyrinejjimų ataskaita, LIIA, f. 1, b. 1712.

114 V. Daminaitis, Žemès kasimo darbų archeologinės priežiūros Vilniaus m., Kosciuškos g. Nr. 28, ataskaita, LIIA, f. 1, b. 2009; G. Stankevičius, Žvalgomujų archeologinių tyrimų Vilniuje, Kosciuškos g. nr. 3, ataskaita, LIIA, f. 1, b. 2064; B. Sipavičienè, V. Steponaitis, E. Valionis, 'Žvalgomieji tyrinèjimai T. Kosciuškos gatvèje 3', Archeologiniai tyrinejjimai Lietuvoje 2009 metais (Vilnius, 2010), pp. 411-421; V. Vainilaitis, Žvalgomieji archeologiniai tyrimai Vilniuje, T. Kosciuškos g. 13 a., LIIA, f. 1, b. 2145; K. Katalynas, Žvalgomieji archeologiniai tyrimai Vilniuje, Kosciuškos g. 36, ataskaita, LIIA, f. 1, b. 2204; Sarcevičius, Žvalgomųjų archeologinių tyrinèjimų, vykdytų 1998 m. Vilniuje, T. Kosciuškos gt. nr. 24, ataskaita, LIIA, f. 1, b. 3136. 
arises in the current area of the War Museum, in which the mentioned gullies intersect. We can gain some knowledge about the old road network of this area from the description of the Altarija plots. ${ }^{115}$ The earliest available sources, going back to the 16 th and 17 th centuries and also later documents, testify to the existence of two main roads. They are the Vilnius-Viršupis and Užupis-Viršupis highways. ${ }^{116}$ From their description, it becomes clear that in the current area of the War Museum, these roads intersect and lead further in the direction of Nemencinè. In our opinion, the network of roads reflects the sites of current and former ditches. ${ }^{117}$ Some of the highlands (Au13-17) that were closest to the approaches of the Crooked Castle and adjoining the main highway may also have had a defensive purpose. ${ }^{118}$

\section{Conclusions}

On the basis of data from interdisciplinary research based on nondestructive methods, the paleorelief (Fig. 3) of Vilnius' medieval

115 J. Sarcevičienė, Sklypų, vadinamų Altarija, suformavimas, užimama teritorija ir istorinè raida (Vilnius, 2009), Vilniaus pilių valstybinio kultūrinio rezervato direkcijos archyvas, T-72.

116 Vilnius-Viršupis, Užupis-Viršupis roads mentioned in these documents: 22 December 1633 letter from the Breslauja marshall Kristupas Rudamina Dusetiškis, by which he records the house (manor) in Antakalnis to the Benedictine (nuns) of Vilnius, LMAVB, f. 273-2183. 23 December 1677 letter of the Jasinskiai chapel priest (pastor) Vincentas Stanislovas Valavičius, by which he distributes to the residents the plots of the Jasinskis Foundation devastated during the war, for which they will pay a cinšas to the chapel. LMAVB, f. 273-2599. 26 August 1619 Mikalojus Jasinskis records a plot in Antakalnis to his servant Ambraziejus Gambrovičius, and obliges him to pay a tax for the shelter home of St Peter's Church. LMAVB, f. 264-1046.

117 One can see a schematic network of roads in the 1899 plan of Vilnius. Here we see that one road to Viršupis went across the bridge over the Vilnia in the direction of the Sluškai Palace, by passing it on the south side, in part of the hills (Au13-15, R18, 19), while the other went through Užupis, the current Olandų Street. However, the plan already reflects the later situation of the road to Viršupis. In it, one can see well the rudimentary section of the road, the extension of which runs through the gullies near Table Hill (R20, 16), LMAVB, f. 229, b. 999.

${ }^{118}$ Although some of them have been investigated by archaeologists (Au17, 18), however, after evaluating the scale of the works, in our understanding the categorical conclusion of the researchers, denying the presence of the Crooked City in these heights, are somewhat hasty. D. Misiukaite, Vilniaus pilių muziejaus-draustinio teritorijos ribu nustatymas. Žvalgomieji archeologiniai tyrimai. Ataskaita. 1990 m., LIIA, f. 1, b. 1668; Katalynas, 1994 m. Žvalgomujų archeologinių tyrinèjimų Vilniuje, Olandų gatvès rajone, ataskaita. 1995. LIIA, f. 1, b. 2349. 
city-castle, called the Crooked Castle (Curvum castrum), was recreated. The research conducted revealed that the terrain of the hill on which the castle was built has been altered significantly. The first changes to the relief are observed in the 14th century, when a new bed for the Vilnia was dug, separating Bald Hill and the Lower Castle from the Crooked Castle. Available data shows that after the decay of the Crooked Castle-City (end of the 14th century), the invasion into the terrain of the analysed hills began at the end of the 17th century, when digging down the adjacent hills, and the Sluškai Palace was built. However, in 1831 the military fortifications of the Russian fortress changed the terrain beyond recognition. For military reasons, all the dominant heights that were next to Bald Hill were lowered, negative forms of the relief, the gullies, were filled in, entire areas of the hills were excavated, and naturally formed areas were raised. Thus, Bald, Table and Bekešas hills and their ridges, as well as the amphitheatres joining them, reached our times either very changed, or like some of the hills in the direction of Antakalnis, in the course of history, disappeared completely from the current landscape.

In our investigations, the restored paleorelief of the Crooked Castle and neighbouring areas shows that the Crooked Castle-City had a more complex three-dimensional structure than was commonly believed. In part of the inner enclosure of the Crooked City, fenced in by a wooden defensive wall, the complex genesis of the relief of Table Hill became clear. In the submitted reconstruction of the relief, we can see that its current area was essentially formed by digging down the separate heights, and filling up the gullies dividing them, which are possible axes of communication. Their location would indicate that some of them could have been used in the inner space of the Crooked Castle-City, while others were associated with communication with the exterior. In the middle of the Crooked City, two axes of roads stand out. They connected the northern amphitheatre with the southern, the former outer baileys. A central hill, only small fragments of which have survived, divided the latter. Functionally, this hill connected Bald Hill with Table Hill. At their ends, strategically important communication nodes formed. The differences between the paleorelief and the current relief are especially apparent on the western slope of Bald Hill, by the River Vilnia. The gullies discovered here would testify that access to the amphitheatre of Bald Hill could not only be from the north, but also from the west. 
The gullies of the slope are located consistently with regard to the roads of the current city. The identified network of washes shows that the strong links that the Crooked Castle had with other parts of Vilnius influenced the development of the entire city. Thus, the concept of the genesis of Vilnius changes: in the 14th century the city evolved not only from the complex of the Upper-Lower castles, but was equally influenced by two centres, the Crooked and Lower castles. This situation determined that in the early period the city expanded not only and not so much in the direction north-south of the Vilnia, but that the west-east axis dominates. Historical events influencing the disappearance of the Crooked Castle-City determined that from the end of the 14th century to the beginning of the 15th century, only the area of the current Old Town was urbanised, and the early axis remains only as a vestige.

\section{Author Details}

Virgilijus Pugačiauskas is a doctor of humanities, and head of the Department of the 19th-century history of the Lithuanian Institute of History. Research interests: Lithuanian history in the first half of the 19th century, the socio-topography of the city of Vilnius.

Address: Lietuvos istorijos institutas, Kražių 5, LT-01108 Vilnius.

E-mail: pugaciauskas@istorija.lt

Saulius Sarcevičius is a junior researcher at the Urban Research Department of the Lithuanian Institute of History, and a doctoral candidate with the Lithuanian Institute of History and Vilnius University. Research interests: the history of Vilnius, construction ceramics and their technology.

Address: Lietuvos istorijos institutas, Kražių 5, LT-01108 Vilnius.

E-mail: sausarii@gmail.com

Oksana Valioniene is an urbanist, a junior researcher at the Urban Research Department of the Lithuanian Institute of History, and a doctor of humanities. Research interests: the history of the medieval city, investigations into the development of the spatial structure of Vilnius.

Address: Lietuvos istorijos institutas, Kražių 5, LT-01108 Vilnius.

E-mail: o.valioniene@gmail.com 


\section{References}

BALINSKIS, M. Vilniaus miesto istorija (Vilnius, 2007).

DAUGUDIS, V. 'Nauji duomenys apie Vilniaus Plikojo (Trijų Kryžių) kalno praeiti', Lietuvos mokslas, t. 2, kn. 2-3 (Vilnius, 1994).

DAUGUDIS, V. 'Vilniaus Plikojo kalno archeologiniai kasinejimai', Archeologiniai tyrinejimai Lietuvoje 1988 ir 1989 metais (Vilnius, 1990).

DAUGUDIS, V. 'Vilniaus Plikojo kalno archeologiniai kasinejimai', Archeologiniai tyrinejjimai Lietuvoje 1990 ir 1991 metais (Vilnius, 1992).

DAUGUDIS, V. Iš Vilniaus miesto praeities (Vilnius, 1993).

DRĖMA, V. Dingęs Vilnius (Vilnius, 1991).

DRĖMA, V. Vilniaus namai archyvu fonduose, VII knyga (Vilnius, 2003).

Enciklopedinis karybos žinynas (Vilnius, 2008).

GOLUBOVIČ, V. GOLUBOVIČ, E. 'Krivoj gorod Vilno', Kratkyje soobcenyje o dokladah i polevyh isledovanyjah instytuta materialnoj kultury, 9 (1945).

GUOBYTĖ, R. 'Vilniaus pilių teritorijos egzotiškasis reljefas ir gelmių sandara', Lietuvos pilys, 3 (Vilnius, 2007).

HOŁUBOWICZ, W. Krzywy gród z XIV w. na górze Bekieszowej w Wilnie (Wilno, 1939).

JAKOVLEV, V.V. Istorija krepostei (St Petersburg, 1995).

JONAITIS, R. KAPLŪNAITĖ, I. Žvalgomieji tyrinejjimai ir žvalgymai T. Kosciuškos g. 10-12, Archeologiniai tyrinejjimai Lietuvoje 2008 metais (Vilnius, 2009).

JURGINIS, J., MERKYS, V., TAUTAVIČIUS, A. Vilniaus miesto istorija (Vilnius, 1968).

JURKŠTAS, J. Senojo Vilniaus vandenys (Vilnius, 1990).

KARALIUS, L. 'Tiltai, pervažiuojamieji perkolai, kamšos, pagrandos, mediniai grindiniai, pylimai Lietuvos Didžiosios Kunigaikštystės sausumos keliuose XVI amžiuje', Lietuvos istorijos metraštis, 2008/1 (2009).

KRASZEWSKI, J.I. Wilno od początków jego do roku 1750 (Wilno, 1840).

KURCZEWSKI, J. Koscioł zamkowy czyli katedra Wileńska, 1-3 (Wilno, 1909-1916).

LIGUZ, J. 'Plan Wilna Georga Maxa von Fürstenhoffa jako źródło historyczne', Kartografia wojskowa krajów strefy baltyckiej XVI-XX w. Materiaty konferencji naukowej, Toruń, 20-22 października 1994 r., Alexandrowicz, S., Karpus, Z., Rezmer, W. (eds.) (Torun, 1996).

ŁOWMIAŃSKA, M. Wilno przed najazdem moskiewskim 1655 roku (Wilno, 1929).

MEILUS, E. 'Vilniaus Pilių apsiaustis ir išvadavimas iš maskvėnų (1660-1661 m.)', Vilniaus Žemutinè pilis XIV a.-XIX a. pradžioje. 20052006 m. tyrimai (Vilnius, 2007). 
MICHELEVIČIUS, D., SARCEVIČIUS, S. 'Šiuolaikinių geofizikinių, geologinių ir kartografinių metodų taikymas Vilniaus Kreivosios pilies beieškant', Geologijos akiračiai, 1 (Vilnius, 2012).

OCHMAŃSKI, J. 'Krzywy gród Wilenski. Proba lokalizacji', Zapiski historvczne, 36 (1971).

ROWELL, S.C. 'Ką ankstyvieji rašytiniai šaltiniai byloja apie Kreivosios pilies vietą', Lietuvos pilys, 4 (2008).

SARCEVIČIUS, S. 'Dainų slènio paslaptys', Lietuvos pilys, 4 (2009).

SARCEVIČIUS, S. 'Stalo kalno paleoreljefo tyrimai Vilniuje', Miestu praeitis, 3 (2012).

SARCEVIČIUS, S. 'Tyrimai Vilniuje, Kalnų parko teritorijoje esančiame Stalo kalne', Archeologiniai tyrinèjimai Lietuvoje 2009 metais (Vilnius, 2010).

SARCEVIČIUS, S., VALIONIENĖ, O. 'Vilniaus Kreivosios pilies paleoreljefas, jo ịtaka miesto genezei’, Lietuvos pilys, 6 (2011).

SIPAVIČIENĖ, B., STEPONAITIS, V., VALIONIS, E. 'Žvalgomieji tyrinėjimai T. Kosciuškos gatvèje 3', Archeologiniai tyrinejimai Lietuvoje 2009 metais (Vilnius, 2010).

SLIESORIŪNAS, F. Gedimino aikštè Vilniuje (Vilnius, 1980).

STANKEVIČIUS, Z., KALANTAITĖ, A. 'LIDAR žemès paviršiaus supaprastinimo algoritmų parametrų parinkimas', Geodezija ir kartografija, 2(35) (2009).

TAUTAVIČIUS, A. 'Kreivosios pilies lokalizavimo klausimu', Vilniui 650 metu (Vilnius, 1976).

TAUTAVIČIUS, A. 'Iš XIV a. Vilniaus gyventojų buities', Iš lietuviu kultūros istorijos, 1 (Vilnius, 1958).

TAUTAVIČIUS, A. 'Vilniaus pilies teritorijos archeologiniai kasinejjimai', Valstybinès LTSR architektūros paminklu apsaugos metraštis (Vilnius, 1960).

VAITKEVIČIUS, G. 'İžanginès mintys apie Kreivaji miestą', Lietuvos pilys, 5 (2009).

VAITKEVIČIUS, G. 'Vilniaus ịkūrimas', Vilniaus sasiuviniai, 1 (2010).

VAITKEVIČIUS, G. 'Vilniaus tapsmas', Miestu praeitis, 2 (2010).

VAITKEVIČIUS, G., KIŠKIENĖ, L. 'Kreivasis miestas', Miestu praeitis, 2 (2010).

VASILEVSKIJ, V.S. 'Gde nahodylsia Vilenskij Kryvoj gorod?', Trudy IX arheologyćeskogo sjezda v Vilne (1893), t. 2 (Moscow, 1897).

VODZINSKAS, E. 'Vilniaus miesto Gedimino kalno geologiniai ir geomorfologiniai bruožai', Lietuvos TSR geografine draugija. Geografinis metraštis, 3 (Vilnius, 1960). 


\section{LIST OF ILLUSTRATIONS:}

Fig. 1. Kalnų Parkas Research. Consolidated plan of the existing terrain (author O. Valionienė)

Geological drillings (research in 2008-2011)

Geophysical research area (research in 2008-2011)

Areas of (in 1993-1998)

1. Approximate location of archaeological research in 1933 (V. and E. Golubovič)

2. Archaeological research in 1939 (V. and E. Golubovič)

3, 4. Archaeological research in the Valley of Songs in 1956 (A. Tautavičius) LIIA, f. 1, b. 40

5. Archaeological research on Bald Hill in 1989 (V. Daugudis), LIIA, f. 1 , b. 1611

6. Archaeological research on Bald Hill in 1991 (V. Daugudis), LIIA, Fund of Drawings, br. 12670-12690

7. Archaeological research at Kosciuškos St 3 (S. Sarcevičius) LIIA, f. 1, b. 2894-2896

I. The Sluškai Palace

II. The Stadium

III. Table Hill

IV. Bald Hill (Three Crosses Hill)

V. The Hill of Gediminas' Grave

VI, VII. Scanning hills (according to S. Lasavickas)

VIII. The Valley of Songs

IX. Sereikiškès

X. Bekešas Hill

XI. The area of the War Museum

Fig. 2. Cartogram of the changes in the terrain on the current terrain (O. Valionienè)

A Filled soil

B Dug out soil

C Natural erosion

Currently known areas of filled soil:

1. Fillings from various periods, the uppermost belongs to the 19thcentury fortress

2, 17, 18. Fillings from various periods

3. The filled area of the caponier of the 19th-century fortress 
4-9. The covered gullies at the time of the construction of the 19thcentury fortress

10. The believed site of the southern amphitheatre, filled in the 19th century.

11. 19th and 20th-century fillings in the area of the War Museum

12. 20th-century fillings related to the straigthening of roads

13, 14. Early 20th-century fillings, related to the

construction of the stadium

15, 16. 19th-century covered gullies on the western slope of the hills.

Currently known areas of excavated soil:

1, 2. 20th-century trenches on the slopes of the hills

3-6. 20th-century excavations related to the straigthening of roads excavated hill in the second half of the 20th century

8-13, 16-18. Heights lowered during the 19th-century construction of the fortress

19th-century excavated chine

Re-dredging, most likely related to the 19th-century unfinished construction of the pill-box of the fortress

19. 14th-century destroyed chine

Note: The earliest excavations in the area of the Sluškai Palace were fixed at the end of the 17 th century

Fig. 3. Reconstruction of the primary relief of Kalnu Parkas. Horizontal step - one metre (O. Valionienè)
A Axis of the gullies
$\mathrm{B}$ Axis of the ridges
C Boundaries of the natural amphitheatres
Microforms of the terrain. Abbreviations for names
Am3 Amphitheatre no. 3
R15 Gully no. 15
K5 Ridge no. 5
Au12 Heights no. 12
B2 Chine no. 2

Fig. 4. Detail of a Vilnius map from 1808. For Legend, see Fig. 3 
VILNIAUS KREIVOJO MIESTO PALEORELJEFO REKONSTRUKCIJA

INTERDISCIPLININIAIS METODAIS

Santrauka

VIRGILIJUS PUGAČIAUSKAS, SAULIUS SARCEVIČIUS, OKSANA VALIONIENE

Nuo 2008 m. atliekami kompleksiniai tyrimai Vilniaus kalnų parke atskleide, kad kalvyno pirminis reljefas buvo ypač smarkiai keičiamas nuo $1831 \mathrm{~m}$., kai šioje teritorijoje buvo pastatyta carinè tvirtovè. Kariniais tikslais buvo žeminamos dominuojančios aukštumos, užpilamos reljefo neigiamos formos - raguvos, nukasinėjami ištisi kalvyno plotai, aukštinamos natūraliai susiformavusios aikštelès - amfiteatrai. Paskutinè ryški invazija, lėmusi kalvyno reljefo pokyčius, įvyko ịrengiant kalvyno teritorijoje Dainų estradą. Mūsų tyrimų metu atkurtas Kreivosios pilies bei gretimų teritorijų paleoreljefas rodo, kad Kreivoji pilis-miestas turejo kur kas sudètingesnę erdvinę struktūrą, nei buvo ịprasta manyti. Pagrindinès kalvyno mikroformos - Plikasis, Stalo, Bekešo kalnai su kalvagūbriais bei jas jungę amfiteatrai - mūsų dienas pasiekè arba labai pakitusios, arba, kaip kalvyno dalis Antakalnio kryptimi, ilgainiui visiškai išnyko. Ypač pasikeitusi kalvyno dalis Stalo kalno vietoje. Iš esmès dabartinè jo aikštelẻ buvo suformuota nukasant atskiras aukštumas bei užpilant jas skyrusias raguvas. Nors konkrečių, mūsų tyrimais aptiktų, mikroformų itakos Kreivosios pilies gynybinèje schemoje, pasiūlytoje ankstesnių tyrëjų, suvokimas yra tolesnių tyrimų objektas, tačiau kai kurias įžvalgas galime daryti jau dabar. Pirma, tyrimų metu išryškèjęs raguvų tinklas yra potencialios komunikacijų ašys. Jų lokalizacija rodytų, kad vienos jų galèjo būti naudojamos Kreivosios pilies-miesto vidinejje erdveje, o kitos buvo skirtos susisiekti su išore. Kreivojo miesto viduje išsiskyrė dviejų kelių ašys. Jos junge šiaurinį amfiteatrą su pietiniu - buvusiais papiliais. Pastaruosius perskyré centrinè kalva, kurios tik nedideli fragmentai išliko iki mūsų dienų. Funkciniu požiūriu ši kalva jungè Stalo kalną su Plikuoju. Ties jo galais buvo susiformavę strategiškai svarbūs komunikaciniai mazgai (3 pav.). Paleoreljefo ir dabartinio reljefo skirtumai ypač akivaizdūs Plikojo kalno vakariniame šlaite ties Vilnia. Čia aptiktos raguvos (R1, R2, R3, R13, R14) bylotų, kad ị Plikojo kalno amfiteatrą (Am1) galèjo būti patenkama ne tik iš šiaurinès (R4), bet iš vakarinès pusès. Jau dabar matyti, kad raguvos šlaite driekiasi dėsningai miesto 
atžvilgiu, ir pagrindinès kelių trasos nukreiptos ị jas, o kiekvienos iš jų konkrečią įtaką miesto struktūrai turètų atskleisti šlaitų tyrimai.

Išryškẻjęs raguvų tinklas rodo, kad buvęs stiprus Kreivosios pilies ryšys su kitomis Vilniaus dalimis veikè visą miesto raidą. Tad keičiasi Vilniaus genezès koncepcija: XIV a. miestas vystėsi ne tik nuo Aukštutinès-Žemutinès pilių komplekso, bet lygiai taip pat buvo veikiamas dviejų židinių - Kreivosios bei Žemutinès pilių ${ }^{1}$ (11 pav.: B). Ši situacija lemè, kad ankstyvuoju laikotarpiu miestas plètèsi ne tik ir ne tiek šiaurès-pietų, Vilnios, kryptimi, bet vyrauja vakarų-rytų ašis. Istoriniai ịvykiai, paskatinę Kreivosios pilies-miesto išnykimą, lèmé, kad nuo XIV a. pab. - XV a. pr. urbanizuojama tik dabartinio senamiesčio teritorija, o ankstyvoji ašis išlieka tik kaip rudimentas. Tad dabar S. Lasavicko XX a. 7 dešimtmetyje iškelta idejja dèl galimos papilio gyvenvietès Antakalnio-Viršupio-Nemenčinès-Polocko kryptimi iggauna realų pagrindą. Tai liudytų kol kas negausūs archeologiniai duomenys, senoji kartografija bei raguvų, atspindinčių senujų kelių vietas, išsidèstymas reljefe. Tad ateities tyrimai teritorijoje tarp Stalo kalno bei Olandų gatvės igauna svarbią reikšmę Kreivosios pilies tyrimų kontekste.

${ }^{1}$ O. Valioniené, Viduramžių Vilnius: planinès struktūros raida XIV-XV a., Lietuvos pilys, 4 (2009), p. 54-61. 